C THE LONDON SCHOOL

OF ECONOMICS AND

POLITICAL SCIENCE

\title{
The Impact of Public
}

Transportation and Commuting on Urban Labour Markets: Evidence from the New Survey of London Life and Labour, 1929-32

Andrew Seltzer, Royal Holloway \& LSE, and Jonathan Wadsworth, Royal Holloway

September 2021 


\title{
The Impact of Public Transportation and Commuting on Urban Labour Markets: Evidence from the New Survey of London Life and Labour,
} $1929-32$

Andrew Seltzer and Jonathan Wadsworth

Keywords: Commuting, public transport, labour markets, New Survey of London Life and Labour

JEL codes: N34, N94, J31

\begin{abstract}
This paper examines the consequences of the commuter transport revolution on working class labour markets in 1930s London. The ability to commute alleviated urban crowding and increased workers' choice of potential employers. Using GIS-based data constructed from the New Survey of London Life and Labour, we examine the extent of commuting and estimate the earnings returns to commuting. We obtain a lowerbound estimate of two percent increase in earnings per kilometre travelled. We also show that commuting was an important contributor to improving quality of life in the early-twentieth century.
\end{abstract}

\section{Introduction}

Urban industry tends to cluster in fairly small geographic areas due to economies of scale and agglomeration. Prior to the mid-nineteenth century, London was characterized by workplace concentration with considerable geographic clustering. Workplace concentration coupled with the inability of workers to

\footnotetext{
- Please address any correspondence to Andrew Seltzer (a.seltzer@rhul.ac.uk). We wish to thank Jessica Bean for discussions early in the project. We also wish to thank Simon Abernathy, Mark Edele, Rob Gillezeau, Dan Hamermesh, Tim Leunig, Nigel O'Leary, Bruce McClung, and Jens Wrona for useful comments and suggestions. We have also benefitted from comments from participants at seminars at Royal Holloway, London School of Economics, University of Melbourne, University of Swansea, Lund University, the Economic History Society Annual Conference, Frontier Research in Economic History Conference, the Economic History Association Annual Conference, the World Congress of Cliometrics, the Australasian and Asian Society of Labour Economists, Labour Markets and Living Standards in Britain Conference, Exploring the Breadth of Labour Economics Conference, the World Economic History Congress, and the Urban History Group. The usual disclaimer applies.
} 
commute meant that virtually all workers lived near their place of work (Heblich, et al 2020). Consequently, the population density of inner London was extremely high, with some working-class areas, such as the Whitechapel District, containing over 50,000 residents per square kilometre in the late-nineteenth century (1891 UK Census). Residential concentration created significant negative crowding externalities in the newly industrialised cities. Much of the debate about the early Industrial Revolution examines whether the increase in standard of living associated with higher wages outweighed the costs of higher population density (Lindert and Williamson 1983; Komlos 1998). However, by the later-nineteenth and early-twentieth centuries, improved transport, allied to investment in public housing began to alleviate many of the problems associated with crowding.

Prior to the development of suitable infrastructure, commuting even moderate distances was infeasible as available forms of travel were slow and expensive. The commuting revolution began with railways in the mid-nineteenth century (Crafts and Leunig 2005; Leunig 2006; Heblich, et. al. 2020). By the end of the century, virtually the entire modern rail Greater London network had been built. Railways offered a far faster means of transport than anything powered by horses or humans. However, rail commuting was mostly limited to the middle class and wealthy well into the twentieth century (Dyos 1982; Polasky 2010). Contemporary and later accounts generally agree that most working-class Londoners continued to live very near their workplace into the early-twentieth century (Booth 1902; Ponsonby and Ruck 1930; Polasky 2010).

Much of the modern bus, tram, and London Underground networks were built in the early-twentieth century. As we show below, by 1930 virtually all residents living within about 15 kilometres of the City of London lived within a few hundred meters of public transport. Unlike the railroads, these transport networks crossed the central areas, making it possible to commute within the inner boroughs at relatively high speed and low cost. Buses and trams had near-universal coverage, with most households in central areas being a fairly short walk away from a stop. The Underground had its own dedicated tracks, making it considerably faster and 
more reliable than buses or trams, although it was also more expensive and geographically limited in coverage. Technological changes, such as the replacement of horse drawn buses and trams by motorised counterparts, meant that the speed and availability of public transport increased dramatically in the early-twentieth century. Concurrently, the average cost per mile travelled declined sharply between 1900 and 1930 .

There is a broad consensus that by the early-twentieth century quality of life was improving across a range of dimensions (Crafts 1997; Easterlin 2000; Prados de la Escosura 2015; Chapman 2019). While the existing literature emphasizes the role of productivity-led increases in income and investment in public health, it is also plausible that investment in public transport played an important role. The availability of relatively high-speed, low-cost transport fundamentally altered the constraint of co-location of workplace and residence. By allowing workers to live away from their jobs, public transport resulted in net movement away from the city centre towards the suburbs. This in turn led to a decline in urban crowding.

Urban and labour economists have emphasized a second effect of commuting, namely increasing the efficiency of labour markets. Competitive theory suggests that identical workers would be paid identical wages regardless of commute - or that unobserved worker attributes underlie any difference in earnings. It also allows for the possibility that employers could pay higher wages to compensate for attracting workers into a central business district or a remote location (Gibbons and Machin 2006). Search theory emphasizes that productivity often depends on the specific match between workers and firms (Mortensen and Pissarides 1994; Rogerson, et al. 2005). Public transport reduces the travel cost for employees and thus allows them to search across and commute to more potential employers (Gibbons and Machin 2006). This, in turn, leads to better matches between workers and firms.

A second potential labour market effect of improved public transport is a reduction of employers' monopsony power (Bhaskar and To 1999; Bhaskar, et. al. 2002, 
Manning 2003a). Manning (2003b) suggests that acceptable job offers may rise with distance commuted, so generating a positive relationship between distance commuted and wages. Workers may also be willing to accept lower wages to avoid the disutility of longer commuting time. As such, travel costs create a wedge between net wages (wages less commuting costs) earned at local and distant employment. This wedge may give employers local monopsony power, as workers' threat to switch employers is constrained by their commuting costs. Monopsony power may also derive from differentiated worker preferences over non-wage attributes across employers. Employers who need large numbers of workers, particularly non-local workers, will need to offer higher wages. High-speed, lowcost public transport reduces employers' monopsony power by reducing the cost to the worker of commuting to more remote positions paying higher wages.

Our focus in this paper is on the effects of London's public transport networks on working-class labour markets, circa 1930. We use data from the New Survey of London Life and Labour (henceforth New Survey or NSLLL), a household survey conducted between 1928 and 1932, to examine working-class commuting patterns and the effects of commuting on earnings. The NSLLL surveyed approximately two percent of working-class households residing in the 29 Metropolitan Boroughs and nine adjacent Municipal and County Boroughs. The data contain a range of personal, housing, and employment-related characteristics. Crucially for our purposes, the NSLLL provides two indicators of commuting: 1) expenditures per week on work-related travel and 2) places of residence and work.

We generate GIS coordinates for residences and workplaces, assigning a single centroid to each unique street address or place name. We also generate GIS coordinates for the entire rail, Underground, tram, and bus network in the Greater London area. We use the GIS data to estimate crow-flies distances between residence, workplace, public transport, and two central points - the Bank of England (the commercial centre of London) and Charing Cross Station (the geographic centre of Greater London). These distances provide us with measures 
of commuting distance, access to public transport, and home and workplace centrality.

We use these data to examine working-class commuting patterns. Over 70 percent of workers in the sample had a one-way commute of at least one crow-flies kilometre. The median (mean) distance was 1.94 (3.05) kilometres. Commuting followed the expected geographic pattern for a modern metropolis: there were net flows from outer boroughs to the centre, although there was also a considerable number of individuals who worked locally or reverse commuted. The wealthy central boroughs, particularly the ancient centres of Westminster and the City of London received the largest net commuting inflows.

We also use these distances as independent variables in Mincer-type regressions on labour force status and earnings. Our results show that the probability of employment was higher for individuals residing closer to the centre but was not affected by proximity to public transport. Residing further from the city centre and living close to an underground station resulted in a greater commuting distance and higher probability of having transport expenditures. We also find that a one kilometre increase in distance commuted increased earnings by slightly over two percent. For a substantial majority of workers in the sample, the monetary return was greater than the monetary cost of travel. On the other hand, we do not find particularly large earnings effects for proximity to public transport, although access to the London Underground indirectly increased earnings through its effect on distance commuted. These results, particularly the effect of distance commuted on earnings, are robust to a variety of specifications.

Finally, we compare our results to evidence from the late-nineteenth century. Booth (1902) provides detailed summary information from the Life and Labour of the People of London (LLPL), a household survey conducted in the 1890s. Travel to work was far less of a focus of the LLPL than the NSLLL, suggesting that it was also a less important aspect of working-class lives. Home-work, the most extreme form of absence of commuting, was common across a wide range of 
industries. Few people worked more than a few hundred meters from their residence (Booth 1902; Ponsonby and Ruck 1930). A simple back-of-the-envelope calculation shows that approximately one quarter of the increase in working-class earnings between 1890 and 1930 can be attributed to the effects of increased commuting distance.

\section{Commuting and Labour Markets}

Economic theory offers four mechanisms by which lower commuting costs may increase the efficiency of labour markets. First, lower commuting costs enable workers to search across more potential employers. Manning (2003b) argues that the low arrival rate of new job opportunities in a given location is sufficient to initiate commuting across otherwise identical employers. Workers trade off any disutility of commuting for higher wages. Mortensen and Pissarides (1994) and Rogerson, et al. (2005) argue that if there is a match-specific component of productivity, increased search will lead to better matches between workers and firms and thus to higher productivity and earnings. Second, lower commuting costs improves workers' bargaining position and reduces employers' local monopsony power by reducing the gap between net earnings at local and distant employers (Bhaskar and To 1999; Rotemberg and Saloner 2000; and Bhaskar, et. al. 2002). Third, workers may distinguish between employers in terms of non-wage aspects of the job. Because workers differentiate between employers, the labour supply curve facing individual employers is upward sloping. To attract sufficient numbers of workers, employers may need to recruit outside their immediate area. The cost of commuting thus affects individual employers' labour supply (Bhaskar, et. al. 2002). Finally, employers who are geographically isolated may need to pay higher wages as a compensating differential to attract workers. Improvements in public transport will reduce the cost of travelling to a previously isolated location, lowering the compensating differential necessary to attract workers (Gibbons and Machin 2006). 
Figure 1 shows the relationship between commuting and earnings diagrammatically. In this framework both workers and jobs are either skilled (denoted S) or unskilled (denoted U). Skilled jobs pay $\mathrm{W}_{0, \mathrm{~S}}$ and unskilled jobs pay the lower wage $\mathrm{W}_{0, \mathrm{U}}$. Unskilled jobs can be done by either skilled or unskilled workers, but skilled jobs can only be done by skilled workers. Jobs also differ in distance from workers' homes but are homogeneous in terms of other attributes. The horizontal axis represents physical location, with the worker's home at the origin and moves to the right reflecting increasing travel distance. The vertical axis is the worker's net wage, e.g. (wage - commuting costs). Commuting costs include both monetary and time costs; and we assume they increase linearly with distance travelled in order to simplify the diagram. Finally, we make the simplifying assumption that workers' place of residence is exogenously fixed, deferring the issue of residential choice until Section VI.

The impact of public transport on increased search and better employer/employee matching can be seen in Figure 1. In the absence of public transport, the net wage for a skilled worker in a skilled job is shown by Ws and the net wage for any worker in an unskilled job by Wu. The gap between $\mathrm{W}_{\mathrm{S}}$ and $\mathrm{Wu}_{\mathrm{U}}$ reflects match-specific productivity, which occurs when a skilled worker finds a skilled job. Jobs are not located everywhere, so W $\mathrm{S}$ and $\mathrm{W}_{\mathrm{U}}$ do not show the actual opportunities of workers, rather the net earnings at all possible locations, conditional on job availability. The reservation net wages are $W_{S}^{*}$ and, $W_{U}^{*}$, for skilled and unskilled workers respectively. If net wages fall below these levels, they choose not to work. We assume the reservation net wage to be higher for skilled than unskilled workers (i.e. skilled workers are more productive outside the labour market). A skilled worker maximizes their net wage by taking the closest available skilled job between home and 14. If there are no skilled jobs available in this range, they then compare available skilled jobs between 14 and 15 and unskilled jobs between home and 10. If there are no unskilled jobs inside 10 or skilled jobs inside 15 , they choose not to work. An unskilled worker maximizes their net wage by taking the closest unskilled job to their home or, if there are no jobs available inside distance 11, by not working. 
Now we consider the effects of building public transport along the space represented by the horizontal axis. The cost of commuting declines along the transport route, and thus the net wage curve shifts up. Note that this is directionspecific, the net wage in other directions does not change. This is shown by the new wage curves $W_{U}^{\prime}$ and $W_{S}^{\prime}$. For very short commutes, walking remains less expensive than public transport, and thus the net wage remains unchanged. However, for longer travel, public transport reduces the cost of commuting and thus shifts net wages up. This has two effects on the labour market. First, skilled workers now earn more than their reservation net wage at skilled jobs between 15 and 16 , thus the quality of matches between workers and firms improves. Second, unskilled workers between 11 and 13 and skilled workers between 10 and 12 now earn more than their reservation net wage in unskilled jobs, and thus workers enter the labour force.

A second possible impact of public transport is that it may reduce local monopsony power (Bhaskar and To 1999; Rotemberg and Saloner 2000; and Bhaskar, et al. 2002). The difference in commuting cost between a nearby employer and a more distant alternative gives local employers bargaining power. Employers with perfect information about employees' outside opportunities will be able to set wages at less than marginal revenue product, so long as net wages remain above the worker's next best alternative. This can be seen in Figure 1. Consider an employee working immediately adjacent to their home with the next closest employer is located at ly. In a competitive market, the employee would be paid $\mathrm{W}_{0, \mathrm{~s}}$, their marginal revenue product. However, in the absence of public transport, their outside opportunity is Wy. A perfectly price discriminating monopsonist could pay just above the lower wage $\mathrm{W}_{\mathrm{Y}}$ and still retain the worker. The effect of public transport is to lower the cost of commuting and thus increase net earnings at more distant employers. In Figure 1, building high speed public transport along the horizontal axis shifts the net wage curve up to $W_{U}^{\prime}$ and $W_{S}^{\prime}$. The skilled worker's outside option is now $W_{Y}^{\prime}$, and the local employer must pay at least this amount to retain them. The skilled worker does not switch employers or use public transport, but is now paid a higher wage due to their increased bargaining power. 
A third possible impact of commuting (not shown in Figure 1) results from workers differentiating between employers based on non-wage characteristics. If employers are sufficiently heterogeneous, they will not be close substitutes for each other and thus the labour market will not be perfectly competitive (Baskar, et. al. 2002). Under this sort of monopsonistic competition, individual employers will face upward sloping labour supply curves. Larger firms would have to pay higher wages and also to recruit more remotely in order to attract sufficient workers. If firms can differentiate between employees, they will pay higher wages only to the marginal employees - those who commute greater distances or face higher commuting costs. If differentiation is not possible, larger firms will have to pay higher wages than otherwise equivalent smaller firms in order to recruit remote workers. Even in this case aggregate wages will be correlated with commuting distance because larger firms will recruit from further afield. Monopsony theories can also explain the apparent paradox of ostensibly identical workers commuting in different directions. If vacancies are hard to find, workers may have to search for employment in different areas (Manning (2003).

A fourth possible impact of public transport (which is also not shown in Figure 1) is that it reduces employers' isolation (Gibbons and Machin 2006). Employers will locate in areas that are distant from their potential labour force if these areas offer lower rents, access to raw materials, better distribution networks, etc. However, isolated firms will be less attractive to workers because of higher commuting costs. To attract workers these firms will need to increase wages to the point where they offset these costs; in other words, they need to pay higher wages as a compensating differential. Improved public transport reduces the cost of commuting to distant locations and thus reduces the size of this compensating differential.

\section{Historical Background: The London Metropolis and Its Commuting Infrastructure}

London is a bicentric metropolis with a commercial centre in the City of London and a geographic and political centre in the nearby Metropolitan Borough of 
Westminster. Urban settlement beyond these centres dates back centuries, but accelerated after the rapid increase in population following the Industrial Revolution. Settlement outside the centres occurred in every direction. However, areas north of the River Thames and west of the city centre tended to be wealthier than areas south and east due to the prevailing winds and river flow.

During the period of our study London was administered under the London Government Act, 1899. Under the Act, Greater London was divided into the City of London, 29 Metropolitan Boroughs in the County of London, and a ring of outer boroughs (officially County Boroughs, Municipal Boroughs, and Urban Districts). ${ }^{1}$ Following Ponsonby and Ruck (1930), we classify the 38 Boroughs in the New Survey into central, middle, and exterior rings. ${ }^{2}$

The New Survey area comprised 429.9 square kilometres, about 27 percent of the total area of Greater London. It was the most densely populated part of the metropolis, with about 5,686,000 residents in 1928, approximately 72.4 percent of the total population of the Greater London area. ${ }^{3}$ Within the New Survey area, population density tended to be highest near the centre. ${ }^{4}$ It is likely that predominantly working-class areas surveyed in the New Survey contained much higher population densities than those reported above. ${ }^{5}$

\footnotetext{
1 The London Government Act, 1899 was replaced by the LGA, 1963, which abolished the County of London and restructured the Metropolitan, Municipal, County Boroughs and Urban Districts into much larger London Boroughs. Throughout this paper we refer to Boroughs and Urban Districts as of the time of the New Survey.

2 The central boroughs are Bermondsey, Bethnal Green, City of London, Finsbury, Holborn, St. Marylebone, St. Pancras, Shoreditch, Southwark, Stepney, and Westminster. The middle boroughs are Battersea, Chelsea, Islington, Kensington, Lambeth, and Paddington. The exterior boroughs are Camberwell, Deptford, Fulham, Greenwich, Hackney, Hammersmith, Hampstead, Lewisham, Stoke Newington, Poplar, Wandsworth, Woolwich, and the outer boroughs. The exact location of the individual boroughs can be seen in Figures 3 and 4 .

3 UK Census data, reprinted in London Statistics and Llewellyn-Smith (1930a).

4 The population densities per square kilometre in 1931 were 2303.2, 2127.1, 1007.0, 1323.7, and 499.3 for the central ring, middle ring, exterior ring, New Survey area, and Greater London, respectively (London Statistics).

5 We are unaware of data on population density for levels below Metropolitan Boroughs. However, one of the initial reasons for undertaking the both the LLPL and NSLLL was a perception of widespread crowding in these areas (Booth 1902; Llewellyn-Smith 1930a). It is clear from the summary volumes of both surveys that working-class dwellings were small, often crowded, and located close together (Booth 1902; Llewellyn-Smith 1930b). The NSLLL data also show that approximately 7.7 percent of households and 12 percent individuals lived in crowded households,
} 
As with most modern cities, London was characterised by economies of agglomeration and a resulting industrial concentration. Textiles, furnituremaking, and box-making were heavily concentrated in the East End; the docks were located by the rivers and major canals; banking, finance, and insurance and their associated clerical employment were concentrated centrally in the City of London. To examine population and employment densities more formally, we have constructed spatial Herfindahl indexes. ${ }^{6}$ The New Survey area contains 36 residential boroughs and 37 employment boroughs (including the City of London), and thus a uniform distribution of residences (places of employment) would imply a residential (workplace) Herfindahl index of .027 (.028).

Table 1 shows the estimated indexes for residences, overall employment, and employment in the largest 13 industries. The index for overall employment, 0.038, is slightly higher than for residences, 0.035, which is itself somewhat higher than if residences were uniformly distributed across boroughs. While these numbers seem fairly small relative to the baseline of 0.027 , they reflect considerable concentration. The residential index of 0.035 reflects the fact that there are approximately 9.1 times as many observations in the New Survey data (6,958 vs 763) in the largest residential borough (Islington) as the smallest (Chelsea). The degree of spatial concentration by industry varied considerably. Financial services and "footloose" industries - such as construction, painting, and metal working had similar levels of spatial concentration to residences. Personal services, transport and communications, and some manufacturing industries (typically those dominated by small firms) had higher levels of spatial concentration. Clerical work and printing had substantially higher levels of spatial concentration. It can also be seen in Table 1 (column 2) that the largest share of employment for most industries was in one of the central boroughs.

defined as more than two people to a room (Llewellyn-Smith 1930b; Hatton and Bailey 1998). If crowding is defined by the so-called Manchester standard of over 2.5 individuals to a bedroom (Llewellyn-Smith 1930b), approximately 34.7 percent of households and 46.4 percent of individuals lived in crowded conditions.

${ }^{6}$ Formally, the index is given by $\sum_{B=1}^{N} S_{B}^{2}$ where $\mathrm{SB}$ denotes the share of the population residing or employed in borough B. We exclude workplace observations from Tottenham, Walthamstow, and outside the New Survey area when calculating workplace indexes. 
The concentration of employment in central areas meant that commuting to work was necessary to prevent over-crowding. However, travel was slow until the midnineteenth century. Walking averaged at most five kilometres per hour, and probably somewhat less. ${ }^{7}$ The only faster alternative was horse-drawn hackney carriages (and horse-drawn omnibuses and trams from 1829 and 1861, respectively), which averaged 6-10 kilometres per hour, but were beyond the means of but the very wealthy (London Transport Museum 2020). Consequently, up to the mid-nineteenth century virtually all workers lived nearby their place of employment (Heblich, et. al. 2020). The development of the faster transport infrastructure needed for longer-distance commutes occurred from the midnineteenth through the early-twentieth centuries. Table 2 shows some statistics on speed, coverage, cost, and usage of railways, the London Underground, trams, and omnibuses in 1900-07, 1913, and 1929. The dramatic improvements in public transport shown in Table 2 led to an increase in usage, which far outpaced the population growth over the same period of time.

Railways were first built in London in 1836. The rail network expanded rapidly, and most of the modern network was complete by the end of the nineteenth century. Compared to other available means of transport, trains were fast. In 1907, the average scheduled speed for commuting trains into central London terminal stations was about 32.3 kilometres an hour (Statistics London, 1907). ${ }^{8}$ The availability of fast transport led to the growth of middle-class residential suburbs. The pattern of residential movement away from the centre is particularly evident for the City of London, which experienced a dramatic decline in residential

\footnotetext{
${ }^{7}$ Five kilometres per hour is a widely cited average walking speed first proposed by the Scottish mountaineer William Naismith. However, Naismith's rule assumes level ground, no encumbrances, and no stoppages; and thus urban walking speed was probably substantially slower. We follow Leunig (2006) and assume a walking speed of 4.0 kilometres an hour throughout this paper.

8 London Statistics (1907) shows the inward speed for 20 suburban train routes with terminus at a central London station between 8:00 and 9:00 am. The figure of 32.3 kilometres per hour is the average across these routes, weighted by the number of trains on each route. This figure is consistent with other sources. Leunig (2006) uses surviving train timetables and calculates that the scheduled rail speed for "minor journeys" (inner-city routes with many stops to provide local service) were 30.4 and 32.8 kilometres per hour in 1887 and 1910, respectively.
} 
population from 130,117 in 1801 , to 43,882 in 1891 , and 15,758 in 1931 (UK

Census), although employment continued to grow over this period. ${ }^{9}$

Figure 2, panel A, shows the railway network circa 1930 and the borders of the County of London and the New Survey area. The map of the network shows two important features of rail travel. First, there was extensive coverage of the exterior of the Greater London area. Virtually all built up locations within the area were connected to the centre by rail. Second, rail commuting across the central areas of the City of London and Westminster was much more difficult, as the terminal stations of the network were built on what was the outskirts of the central area when the rail networks were first built in the mid-nineteenth century. ${ }^{10}$ There were few direct connections between the terminal stations. These two characteristics meant that rail travel was typically used for longer-distance commutes from the suburbs to the centre or, less frequently, reverse commuting out from the centre to industrial suburbs.

Although rail commuting transformed the lives of the wealthy and middle classes, most scholars have argued that, with the exception of a relatively small number of relatively high earners, few working-class employees commuted by rail in the nineteenth century. ${ }^{11}$ Ponsonby and Ruck (1930) argue that even circa 1930, rail was a relatively infrequent mode of commuting for the working-class, typically

\footnotetext{
9 The City of London undertook Day Censuses in 1866, 1881, 1891, and 1911 to demonstrate its continued commercial importance. The Reports of the Day Censuses show that many non-residents entered the City every day and that employment increased substantially even as the residential population declined. The estimated daytime population of the City of London was 261,061 in 1881; 301,384 in 1891; 364,061 in 1911; and 436,721 in 1921 (Day Census, 1881-1911 and UK Census, 1921). Table 1 shows that the City of London remained the largest employment location at the time of the New Survey.

10 The opening of the Metropolitan Underground Line in 1863 provided limited connections between the terminal rail stations and the central areas of London. However, coverage was limited and additional ticket cost would have been beyond the means of most working-class employees in the late-nineteenth century.

11 See Ponsonby and Ruck (1930), Dyos (1953), Polasky (2010). Even into the twentieth century, rail commuting from the outer boroughs was not practical for most working-class households. These households often had multiple earners, thereby would have required multiple fares. Working class employees also worked very long hours and thus faced time constr aints and faced sufficiently irregular employment that many could not be sure of work when they would have had to board a train (Booth 1902; Maddison 1964; Huberman and Minns 2007).
} 
used for very long commutes (over 16.1 kilometres) or as a substitute for the Underground in the south and east of the metropolis.

Working-class access to public transport did, however, improve dramatically in the early-twentieth century. New modes of transport made it practical to commute between inner-city locations. New infrastructure and technology, most notably the development of the Underground network and the replacement of horse-drawn buses and trams by their motorised counterparts, reduced the cost and increased the speed and reliability of travel. Buses and trams were cheap, with fares starting at $1 / 2 \mathrm{~d}$, whereas Underground fares were typically $2 \mathrm{~d}$ or more. ${ }^{12}$ The Underground lines, trams, and buses were owned separately, but were regulated under a common framework established under the London Traffic Act of 1924. Public transport companies sometimes competed for passengers on the same route until their consolidation under the London Passenger Transport Act and the formation of the London Transport Board in 1933.13

Although its first underground train line was opened in 1863, the core of the modern Underground network was built in the early twentieth century. The Central London Railway (the Central Line), Baker Street \& Waterloo Railway (the Bakerloo Line), Piccadilly \& Brompton Railway (the Piccadilly Line), and Charing Cross, Euston \& Hampstead Railway (the Northern Line) opened in 1900, 1906, 1906, and 1907, respectively. ${ }^{14}$ The Underground ran at similar speeds to mainline rail. However, unlike the rail network, the Underground network was designed to

\footnotetext{
12 Prices are reported using "old" pounds sterling, where one pound (£) equals 20 shillings (s) and one shilling equals 12 pence $(d)$.

${ }^{13}$ In addition to public transport, bicycles were an important form of transport for the working class. Aldred (2014) argues that bicycles were relatively cheaper and much more widely used for commuting in 1930 than in 1900. It is not possible to determine the exact number of workers commuting by bicycle, as the New Survey recorded transport expenses rather than mode of transport. Nevertheless, commuting by bicycle is specifically mentioned for 288 individuals and it is likely that many individuals with zero or missing commuting expenditures cycled to work. Private cars and motorcycles were beyond the means of almost all workers in our sample. These modes of transport are specifically mentioned for only 12 individuals.

${ }_{14}$ By 1907 the routes that would become the Central, District, Metropolitan, Central, Bakerloo, Piccadilly, and Northern Lines were all largely completed. Although the outer termini of these lines would be extended between 1907 and 1930, no new lines were opened from 1907 until the opening of the Victoria Line in 1969.
} 
cross the inner city, and made it feasible to commute between most locations in the north and west regions of the NSLLL area. The limiting factor on Underground usage was its cost, with 58 percent of journeys in 1930 costing $2 \mathrm{~d}$ or more (Ponsonby and Ruck 1930, p. 187). While the average fare per mile on the Underground was lower than the bus or tram (Table 2), the Underground was more expensive for shorter journeys. Ponsonby and Ruck (1930) argue that circa 1930 the Underground was the primary mode of working-class travel for distances between 3.2 and 19.3 kilometres.

Figure 2, panel B shows the Underground network circa 1930. Unlike the rail network, the Underground network was geographically concentrated, with over 80 percent of stations located north of the River Thames and west of the eastern boundary of the City of London. This concentration occurred for both geological and economic reasons. North of the River Thames, the soil is predominantly "London clay", which is comparatively easy and inexpensive to tunnel through and is largely impermeable to water (Paul 2016). In most areas south of the Thames, the London clay is covered by sand and silt which is porous and difficult to tunnel through. Even today, virtually all of the deep underground rail network is located in the areas where the London clay is near the surface. The boroughs east of the City of London were poorer than those to the west, and the Underground was generally not extended to this area, regardless of geological suitability. 15 The outer parts of the metropolis, with the exception of a few wealthier areas to the north and west, were generally not serviced by the Underground because the density of traffic would not have been sufficient to justify the high initial fixed investment.

Private horse-drawn carriages (or "hackneys") have been used in London for centuries. Horse-drawn omnibuses open to the public were first run in 1829 (London Transport Museum 2020). Horse-drawn trams date back to 1860. In the twentieth century, electric, diesel, and petrol engines replaced horses (London Transport Museum 2020). Circa 1930, buses and trams were similar in terms of

\footnotetext{
15 The entire area east of the City of London contained only one Underground line (District) and 9 stations.
} 
vehicle design, speed, and cost, with the only major difference being that trams ran on fixed lines whereas buses could be run on any road (Ponsonby and Ruck 1930; London Transport Museum 2020). Both were substantially slower than rail or the Underground, but were also cheaper on short routes. Ponsonby and Ruck (1930) argue that workers used buses and trams interchangeably on journeys of up to 3.2 kilometres.

The bus and tram networks circa 1930 are shown in Figure 2, panels C and D. Trams were contained within inner-London, with few routes extending beyond the boundaries of the New Survey area. Tram density was highest in areas without Underground lines. On the other hand, buses were the most widely distributed form of public transport. In 1931 there were 209 routes within Greater London, covering virtually all built-up areas. Virtually all residents of the New Survey area had access to at least one bus route, and only a few households in the outer boroughs were located more than a few hundred meters from a route.

\section{Data}

Our primary source of data are records from the New Survey of London Life and Labour, a household survey of working-class residents of the 29 Metropolitan Boroughs and nine outer boroughs conducted between 1928 and 1932. Most of the original record cards have survived intact, and were encoded in the 1990s by the team of Roy Bailey, Dudley Baines, Timothy Hatton, Paul Johnson, Anna Leith, and Angela Raspin. The original cards from the Municipal Boroughs of Walthamstow and Tottenham, the two northernmost boroughs in the sample, have been lost. ${ }^{16}$ The computerized records are freely available from the UK Data Archive (Johnson, et. al. 1999). The computerized records contain 26,915 households, 94,137 individuals, and 49,445 income earners, about two percent of the working-class population of London.

\footnotetext{
16 The adjacent boroughs of Leyton and Hornsey comprise slightly over 3 percent of the NSLLL sample and thus it is likely that the share of records lost was fairly small.
} 
The NSLLL was created to follow the LLPL, which influences both the sample and the questions. The LLPL surveyed residents of the 29 Metropolitan Boroughs, excluding the City of London, which had few working-class residents by the 1890s. The NSLLL also included the County of London (again excluding the City of London). However, by the late-1920s there had been outward movement of working-class residences, thus the NSLLL also included nine adjacent outer boroughs. ${ }^{17}$

The sample is limited to working-class households, defined by the head of household not working in a white-collar occupation. Most households surveyed earned well below $£ 250$, approximately the median household income in London in 1929. The mean (median) wage earnings for households with at least one income earner was $£ 110 / 14 \mathrm{~s} / 5 \mathrm{~d}(£ 100)$ and only 7.5 percent of households in the sample earned more than $£ 200 .{ }^{18}$

The NSLLL was structured by individual household. Each record card contains background information about each member of the household: age, gender, place of birth (for adults), relation to head of household, and different sources of nonwage income. The cards also contain information on the dwelling: address; borough; rent paid; number of bedrooms; and whether it contains a kitchen, pantry, scullery or larder, bath, parlour, garden, yard, and allotment. Finally, they contain the following additional information for each working member of the household: earnings in the previous week and in a full-time week, hours worked in the previous week and in a full-time week, occupation, employer, place of work, and transport expenditures. A complete list of the information on the record cards

\footnotetext{
${ }^{17}$ These were Acton, Barking, East Ham, Hornsey, Leyton, Tottenham, Walthamstow, West Ham, and Willesden. These boroughs contained the majority of working-class residents of the Greater London area outside the County of London (Llewellyn-Smith 1930a).

18 These figures likely overestimate annual earnings, which we estimate using the standard approach of multiplying pay in a full week by 50 weeks. Some intermittent employment was for less than 50 full-time weeks per year. A rough indication of the extent of intermittency can be obtained by comparing hours worked in the previous week and hours worked in a full-time week. Approximately one percent of those reporting positive hours in a full-time week also reported zero hours in the previous week. Hours worked in the previous week is missing for another 2.5 percent. Approximately 7.0 percent of workers reported working less than full time hours in the previous week, compared to only about 1.0 percent who reported working more than full time.
} 
is shown in Appendix I. Summary statistics for variables used in the paper are shown in Appendix I, Table A.I.1.

For our purposes, the most important feature of the data is that it contains information about travel to work. The only direct information in the data is expenditure on transport. However, using transport expenditure to measure commuting is problematic for our purposes. This information is missing for about 30.8 percent of workers who worked a positive number of hours in the previous week. ${ }^{19}$ In addition, many respondents did not supply easily quantifiable answers to the question about transport expenditures, e.g. "bicycle" or "it varies". Moreover, it is possible that some non-commuting-related travel costs are included in the responses even though the question was clearly intended to cover commuting costs only (see Appendix I). Finally, the monetary cost of travel does not incorporate the implicit costs of workers' time commuting and thus would not reflect the full cost of transport even absent errors in the data. For these reasons, we only use transport expenditures for robustness tests, rather than as the main indicator of commuting in our analysis.

As an alternative to travel expenditure, we measure the crow-flies distances between individuals' residence and workplace, residence (workplace) and the geographic and commercial centres of London, and residence (workplace) and nearest available public transport. To do this, we first generate GIS coordinates for each relevant point of interest using Streetmap.co.uk and National Library of Scotland (2020). For each unique location we generate GIS coordinates for a single centroid, typically at the centre of each street or place name. In addition to home and workplace, we have gathered GIS data for the entire public transport network within the Greater London area. We then used the GIS coordinates and the Great Circle Distance formula to construct several variables measuring crow-flies

\footnotetext{
19 When coding transport costs, we have handled missing observations in two ways. First, we simply leave these as missing and drop the observations from the analysis. Secondly, we recode missing values to zero if the individual's residence and workplace were less than a kilometre apart. We generally prefer the second approach, as one kilometre is a plausible walking distance and virtually no individuals in the data residing within a kilometre of their workplace reported nonzero transport costs.
} 
distances between home, workplace, the nearest public transport, and the nearest centre of London. Appendix II outlines in detail the procedures used to obtain the GIS data and construct the distance variables and the potential sources of measurement error and bias in these variables.

\section{Summary Statistics on Commuting}

Table 3 shows some summary statistics on distances. ${ }^{20}$ The first 8 rows show the mean distances from home and then workplace to the nearest available point of embarkation for each of the four modes of public transport. As would be expected based on Figure 2, the average distance from both home and work is largest for the Underground and smallest for buses. The variance is also much higher for the Underground, due to its incomplete coverage. Table 3 also shows the universality of access to at least some form of public transport. A household two standard deviations above the mean distance from the nearest bus stop, would nevertheless still be in easy walking distance of a stop (520 meters). Only 0.02 percent of income earners in the sample resided more than one kilometre from the nearest available means of public transport.

The next 15 rows of Table 3 show the distribution of crow-flies distances between home and work. The mean and median distances were 3.05 and 1.94 kilometres, respectively; less than modern commutes, but considerably more than "working on the spot", which was typical in the 1890s (Ponsonby and Ruck 1930). ${ }^{21}$ It is also evident that on average 1) men commuted greater distances than women, 2) commuting distance increased with skill, and 3) commuting distance was very similar for heads of households and others. The construction of the sample implies that it is likely that the average commute across the entire London population was

\footnotetext{
${ }^{20}$ Approximately eight percent of workers who report pay were itinerant, with no fixed place of work. We did not assign a commuting distance to these workers. See Appendix II for further details.

21 According to figures from the 2011 UK Census, the average commute for full-time workers in Greater London was 16.4 kilometres (Greater London Authority 2015). The New Survey area comprises the central-most part of Greater London, thus one would expect shorter average commutes than for the Metropolis as a whole.
} 
almost certainly greater than shown in Table 3 because the NSLLL sample only includes workers who lived relatively close to the centre.

The final four rows show the direction of commuting, divided into four mutually exclusive and collectively exhaustive categories: inwards - workplace is at least one kilometre closer to the centre than home, outwards - home is at least one kilometre closer to the centre than workplace, local - distance travelled is less than one kilometre, and across - distance travelled is at least one kilometre but there is less than one kilometre difference in home and workplace centrality. The largest share, (38\%), commuted inward, followed by working locally, (29\%), but around one third of workers in the sample commuted outward or across London.

Figures 3 and 4 explore the patterns of commuting by borough of residence and workplace. Figure 3 shows the workplaces for residents of four boroughs: Stepney (an East End borough adjacent to the City), Lambeth (a largely working-class borough which runs from directly across the river from the City to the southern boundary of the New Survey area), Westminster (the political and geographic centre of the metropolis), and Islington (an inner-north borough with the largest working-class population in the metropolis). ${ }^{22}$ Figure 4 shows net commuting inflows and outflows by borough of residence.

The conclusions from Figures 3 and 4 are fairly consistent, and we summarize them jointly. The general pattern across all residential boroughs was that the largest share of workers either worked within their borough of residence or commuted inwards to the centre. Consistent with evidence from earlier Day Censuses and the 1921 UK Census, the City of London was the largest net recipient of commuters, although the wealthier boroughs north and west of the City were also net recipients. The exterior boroughs were typically "dormitory suburbs", although some had large employers that attracted many workers from other

22 We have constructed similar figures for each of the 36 residential boroughs in the data. This is shown in Appendix IV, Figure A.IV.1. The patterns shown in Figure 4 are common across the remaining boroughs. 
boroughs, such as the Arsenal at Woolwich or the docks at Bermondsey and Poplar.

\section{Empirical results}

\section{i. Estimation Strategy}

The models outlined in Section II imply that proximity to and use of public transport will have direct effects on labour markets. Proximity to public transport reduces the (time) cost of commuting. This in turn leads to a higher likelihood of using public transport and longer commutes, which may lead to higher income through the mechanisms outlined in Section II. In this section, we examine the impact of public transport and commuting using the New Survey data, augmented by the GIS data described in previous sections.

To examine labour force status, we run probit regressions of the general form:

$$
E M P_{i}=a+B X_{i}+b_{2} D_{C E N T H, i}+b_{3} D_{U H, i}+b_{4} D_{\text {TrainH }, i}+b_{5} D_{\text {Tram }, H i}+b_{6 j} D_{B u s H, i}+e_{i}
$$

where:

EMP is a dummy variable taking a value of one if an individual is employed. We define employment as either having an earner number or reporting nonzero working hours in the previous week.

$\mathrm{X}$ - control variables: age, age $^{2}$, age not reported, age $>14$ (the school-leaving age in 1930), sex, born in England, born in London, born in same borough as current residence, born in an adjacent borough to current borough of residence, wage income of other family members, non-wage income of the household, and borough of residence.

DU,H - crow flies distance (CFD) home to nearest underground station.

$D_{\text {Train,H }}-$ CFD home to nearest train station.

$D_{\text {Tram }, H}-$ CFD home to nearest tram stop.

$D_{B U S}-$ CFD to nearest bus stop.

DCENT,H - MIN[CFD home to Charing Cross, CFD home to Bank of England].

To examine distance commuted or use of public transport we run the following regressions: 


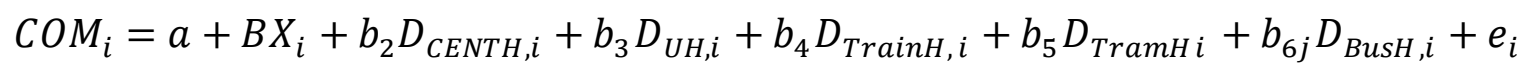

where:

$\mathrm{COM}$ - is a variable indicating the extent of commuting. We define this in several ways: crow-flies distance commuted, whether reporting positive commuting expenditures, whether distance commuted was less than one kilometre, and whether distance commuted was 3.2 kilometres or more. ${ }^{23}$

$\mathrm{X}$ - control variables: age, age ${ }^{2}$, age not reported, sex, hours worked last week, hours worked not reported, born in England, born in London, born in same borough as current residence, born in an adjacent borough to current borough of residence, and borough.

To address the impact of commuting on earnings, we run modified Mincer-type wage regressions (Mincer, 1958 and 1974) of the general form:

$$
\begin{aligned}
\ln \left(\text { Pay }_{i}\right)=a & +B X_{i}+b_{1} D_{E, i}+b_{2} D_{C E N T H, i}+b_{3} D_{U H, i}+b_{4} D_{\text {Train }, i}+b_{5} D_{\text {Tram }, H} \\
& +b_{6 j} D_{B u s H, i}+b_{2} D_{C E N T W, i}+b_{3} D_{U W, i}+b_{4} D_{\text {Train }, i}+b_{5} D_{\text {TramW }, i} \\
& +b_{6 j} D_{B u s W, i}+e_{i}
\end{aligned}
$$

where:

Pay - earnings in the previous week in hundredths of old pence.

$\mathrm{X}$ - control variables: age, age ${ }^{2}$, age not reported, sex, hours worked last week, hours worked not reported, born in England, born in London, born in same borough as current residence, born in an adjacent borough to current borough of residence, skill level, occupation, and boroughs of residence and workplace.

$\mathrm{H}, \mathrm{W}$ subscripts denote home and workplace, respectively.

The frameworks outlined in Section II imply the following for the regression coefficients. Living close to one of the centres implies a higher density of local jobs and lower commuting costs needed to reach a suitable job. Thus, we expect residential centrality to be associated with a higher likelihood of being employed, a lower likelihood of commuting by public transport, and shorter commutes. Proximity to public transport will reduce the (non-monetary) cost of its usage.

\footnotetext{
23 The cut-off points of 1.0 and 3.2 kilometres are selected based on discussion about transport mode in Ponsonby and Ruck (1930). In the data, 92.1 percent of workers with reported expenditures who commuted less than 1.0 kilometres reported expenditures of exactly zero. Among workers with non-missing expenditures commuting over 3.2 kilometres, 89.8 percent reported positive transport expenditures.
} 
Thus, we expect it to be associated with a higher probability of employment and a higher probability of positive transport expenditures.

The effect of proximity on distance commuted is likely to vary across the different modes of public transport. Workers typically used buses or trams for short distances, and trains or the Underground for longer distances (Ponsonby and Ruck 1930). A worker residing nearby a bus or tram would be more likely to use these modes of transport than to walk and thus commute further, but also more likely to use them instead of trains or the Underground and thus have a shorter commute. By a similar line of reasoning, proximity to trains or the Underground would lead to longer commutes for those who use public transport. However, stations, particularly the larger train stations, were themselves important focal points of local employment. This implies an ambiguous relationship between residential access to trains or the Underground and commuting distance. Finally, the frameworks described in Section II imply that greater residential access to

public transport, greater commuting distance, and lower workplace access to public transport will all result in higher earnings.

\section{ii. Endogeneity of Location}

An important econometric issue associated with these regressions is that the locations of both residence and workplace are choice variables and thus there exists the possibility of reverse causality in an OLS regression on the full sample. Income may determine commuting distance by affecting the set of available residential choices. Put simply, a high earning individual could choose to live either near their workplace or alternatively in distant residential suburbs and commute into work. The existence of reverse causation would imply that the estimated coefficients on the distance variables in an OLS regression would be biased, and a priori the direction of the bias is ambiguous. Llewellyn-Smith (1930b) argues that London housing rental markets were very tight circa 1930, and respondents in the NSLLL would not have had the extent of residential choice that would be open to Londoners today. Nevertheless, it is very likely that there 
was at least some degree of residential choice, and it is necessary to mitigate the associated potential biases.

The standard approach to identification with this sort of endogeneity concern would be to use an instrumental variable (IV). However, it is far from clear that the cross-sectional NSLLL data (Appendix I) contains a suitable instrument which will satisfy both of the required exclusion restrictions: e.g. relevance (the instrument must be correlated with the distance variables) and exogeneity (the instrument cannot plausibly directly influence the dependent variable through mechanisms other than its correlation with the distance variables).

Because the standard IV approach is not viable, we have attempted to limit the extent of endogeneity in other ways. First, we restrict our sample to individuals who presumably had the least choice with regard to residential location. There exists a literature in urban economics which assumes that households' residential choices revolve around the primary income earner (Kain 1962; O'Reagan and Quigley 1993, Rees and Shultz 1970). Thus, our preferred regression specification s exclude heads of household and non-family members. Non-relatives (such as lodgers) presumably had the greatest extent of residential choice, and thus these individuals are also excluded from our preferred regression specification. ${ }^{24}$ Because we cannot be sure that our approach of restricting the sample fully mitigates against endogeneity, we have also estimated the regressions splitting the sample several different ways as a robustness check.

Another strategy that will help control for endogeneity caused by any unobserved heterogeneity in location choice is to estimate over all individuals in a household and to include household fixed effects in the estimation. Including household fixed effects means that the distance variables are identified by within-household

\footnotetext{
${ }^{24}$ Heads of household are defined either by the relationships given on the original record cards or by the highest earner within the household. We use the relationship categories from the original record cards to decide whether individuals were related to the head of household. We have excluded individuals if there is ambiguity in the relationship ("single", "bachelor", "spinster") as well as if it is clear that they were unrelated ("lodger").
} 
differences in commuting. This will reveal whether individuals in the same household (and by extension the same location) receive higher wages with distance travelled. This approach will mitigate against biases associated with any unobserved characteristics that also determine wages.

\section{iii. Effects of Public Transport on Labour Force Status and Commuting Distance}

Table 4 shows results for the employment and distance commuted regressions for the sample who are related to the head of household and aged 14 or over. The first two columns show results for the probability of being in work. We report the estimated marginal effects for the explanatory variables of interest. ${ }^{25}$ The last five columns show results for distance commuted. To ensure the robustness of our results, we change the dependent variable in the different specifications, and, in column 4, jointly estimate the effects on employment and commuting distance using the Heckman correction. In this regression, the first stage is identified by the standard "labour supply" variables, wage income of other family members and non-wage income of the household.

While the estimated signs of the distance effects are the same for the two participation specifications, their significance differs. The coefficient on distance from the nearer centre is negative and significantly different from zero in the earner number specification, (column 2) but not the hours worked specification, (column 1). These differences stem from observations with missing hours among self-employed workers, who typically commuted shorter distances. Individuals residing more centrally were more likely to be employed, presumably because of the greater concentration of jobs in the central areas. Closer access to a train station is negatively associated with the likelihood of being in work in the hours worked model. Closer access to a bus stop is positively associated with working. ${ }^{26}$

\footnotetext{
25 The estimated marginal effects for the other explanatory variables are given in Appendix IV, Table A.IV.1.

26 As robustness tests we re-estimate the models using family fixed effects (Appendix IV, Table A.IV.2). We also replaced the distance from public transport variables with the number of train/Underground stations and bus/tram routes in the same 500 square meter grid (and one square kilometre grid) as the individual's residence. The results are qualitatively similar to those shown in Table 4.
} 
The results of the commuting regressions are consistent across specification. Workers residing near one of the centres commuted shorter distances, (columns 3 $\& 4$, row 1), were less likely to incur transport expenses, (column 5 row 1), were more likely to work locally, (column 6 row 1) and were less likely to commute medium to long distances (column 7 row 1). As with the employment regressions, the logical interpretation of this result is that labour markets were much thicker and thus there were more local employment opportunities near the two centres.

Access to the Underground - conditional on distance from the centre - was associated with longer commutes, a higher probability of incurring transport expenses, a lower probability of working locally, and a higher probability of a medium to longer commute (row 3 , columns 3 to 7 ). There is a sharp contrast between access to the Underground and access to the train system, the two transport modes used to commute longer distances. The coefficients on access to the train are much smaller than on access to the Underground and are insignificant in all but one specification, suggesting either that commuting by train was fairly uncommon or that local employment near train stations more-orless offset longer-distance travel by train. The coefficients on distance to bus and tram stops are generally insignificant and the estimated marginal effects small.

iv. Effects of access to public transport and commuting on earnings

Table 5 shows the distance results for the earnings regressions. In the main specification (column 1), we restrict the sample to relatives of the head of household, and thus exclude heads, lodgers, and other non-relatives. In column 2, we jointly estimate earnings and the probability of employment and report the Heckman selectivity corrected earnings estimates on distance. As robustness tests, we further restrict the sample to individuals under age 25 (column 3) and children of the head of household under age 25 (column 4 ). ${ }^{27}$ We also run the

\footnotetext{
${ }^{27}$ Children tended to live with their parents until their late-20s. Among individuals in the sample aged 25 or less, 78.6 percent lived in a household headed by one of their parents, 7.6 percent were the head of household, 10.1 percent were the spouse of the head of household, 2.9 percent lived in a household headed by another relative, and 0.1 lived in a household headed by a non-relative (usually as a lodger). At age 25, 45.4 percent of women and 54.5 percent of men in the sample we re listed as the child of the head of household.
} 
regression using all individuals in the sample (column 5) and add household fixed effects (column 6).28 The control variables in the regressions are generally significant, have the expected sign, and are consistent with other studies estimating earnings (see Appendix IV, Table A.IV.3).

The strongest and most robust results in Table 5 pertain to the distance travelled from home to work. The estimated coefficients on the distance commuted and its square have large, strongly significant effects in every specification. The magnitude of the net effect is very similar across specifications and all household members. A one kilometre increase in distance is associated with slightly over a two percent increase in earnings. The inclusion of household fixed effects does not change the estimated coefficients appreciably. The coefficients can be interpreted as semi-elasticities and imply that, when evaluated at the mean, earnings increased by about two percent for each kilometre commuted. Appendix IV, Table A.IV.5 replaces continuous distance with dummy variables for discrete distance intervals measured relative to a base category of a less than 0.5 kilometre commute. The estimated effects rise montonically but nonlinearly with distance commuted. In Appendix II, we show that the measured crow-flies distance commuted is likely to be an over-estimate, and thus the estimated returns here should be interpreted as a lower bound.

While there is a strong effect for distance commuted on earnings, the effects of the other distance variables are far weaker. The coefficients on both home and workplace centrality are insignificant in nearly every specification. The coefficients on the other access to public transport variables are mostly insignificant and are not robust to specification.

\footnotetext{
28 As further robustness tests, we have also run additional regressions which 1) replace the designated head with the highest income earner in each household, 2) use one kilometre squared grids to measure access to public transport, 3) include only heads of household, 4) replace continuous distance with discrete categories, 5) include very long commutes (50+ kilometre), 6) exclude the occupation and workplace borough dummies, 7) replace occupation dummies with skill categories, 8) exclude observations collected by the most prolific enumerator, G.E. Bartlett, whose accuracy has been questioned in Abernathy (2017). In all cases, the main results are qualitatively very similar to those presented in Table 5. Additional results are shown in Appendix IV, Table A.IV.4.
} 


\section{v. Commuting Costs}

Commuting has monetary and non-monetary costs in addition to the benefits shown in Table 5. Table 6 shows some simple back-of-the-envelope calculations of the returns and costs of 8 "standard" commutes, which are stylized versions of what we observe in the data. The table shows one-way commuting distances and the time, estimated monetary returns, and monetary and implied time costs for each of these commutes. We use information on travel modes and cost from Ponsonby and Ruck (1930) to identify the likely mode of travel and the associated monetary cost. We estimate the returns to commuting at the tenth, twenty fifth, and fiftieth percentiles of the weekly income distribution using the regression results from the first column of Table 5. We estimate the implied time cost by calculating the estimated time spent walking, waiting, and taking public transport for each commute and multiplying this by 50 percent of hourly earnings. ${ }^{29} \mathrm{We}$ assume a walking speed of four kilometres an hour, public transport speeds shown in Table 2, and waiting times of five minutes for bus and tram and eight minutes for train and Underground. Full details of these calculations are shown in Appendix III.

It can be seen in Table 6 that the monetary returns from commuting outweighed the monetary costs for all but the bottom 10-25 percent of earners. Workers above this level of income would not have faced income constraints that prevented them from commuting, as their higher earnings due to commuting would have paid for the monetary costs of travel. Whether these workers would have chosen to commute would thus depend only on whether the total (monetary and nonmonetary) returns outweighed the total costs. It can be seen in Table 6 that time costs were substantial even for low earners, suggesting that most individuals would not have commuted unless there were non-monetary as well as monetary returns.

\footnotetext{
29 This is a fairly typical estimated value of time travel savings from the urban economics and geography literatures (Wardman 1998; Zamparini and Reggiani 2007).
} 
Commuting would have given households greater residential choice, and thus reduced rents or provided non-pecuniary benefits associated with neighbourhoods. It would have also given workers more choices over non-monetary attributes of their job. We cannot observe these benefits for individuals, although we later show that living further away from the centre was associated with lower rents, all else equal. It is likely that there was substantial heterogeneity in both costs and returns, which is consistent with the observed distribution of commuting distances and with a sizable share of workers working locally despite the monetary returns to commuting outweighing the monetary costs for all but the lowest earners.

For workers in the bottom 10-25 percent of the earnings distribution, the monetary costs of commuting outweighed the returns. If these workers were the primary source of income for their household, it is likely that they would have been income constrained, and unable to afford to commute even if the total returns outweighed the total costs. On the other hand, if these workers were secondary earners from wealthier households, it is much less likely that they would have faced income constraints. To determine whether low earners were typically from poor households, we construct household-specific poverty lines using the approach outlined in Hatton and Bailey (1998). The poverty lines are based on minimum required expenditure on food and clothing, rent, and fuel given the structure of each household and actual expenditure on National Insurance and transport. Further details of the construction of the poverty line are available in the appendix of Hatton and Bailey (1998) and Appendix III of this paper. We estimate the share of workers in the bottom 10 percent (25 percent) of the earnings distribution who resided in households under the poverty line to be 25.2 percent (17.3 percent). Although low earners were more likely than the sample as a whole to be below or only slightly above the poverty line, a majority of low earners were secondary earners in wealthier households. These figures imply that only 2.5-4.3 percent of workers in the New Survey data faced income constraints that may have prevented commuting. 


\section{vi. Comparison to the $1890 \mathrm{~s}$}

Ponsonby and Ruck (1930, pp. 171, 191) argue that newly available modes of transport in the early twentieth century led to commuting by the working class, and a fundamental change in the market for their labour, stating, "No change in the last generation has had more far-reaching effects upon the life of the whole community in London than the improvement of transport facilities. ... It must be remembered, above all, in this connection that by far the greatest proportion of the increase (in commuting) is due to working-class travel. In Charles Booth's time [the 1890s] workmen travelled but little, being generally employed on the spot." The evidence on commuting in companion volumes to the LLPL is largely indirect, but also suggests that most working-class employees in the 1890s did not commute. There are only a few direct references to working-class commuting in these volumes, generally pertaining to footloose occupations such as the building trades (Booth 1902, Vol. IX, p. 17, Vol. V, p. 125). ${ }^{30}$ The LLPL volumes do, however, contain numerous mentions of outwork from home, the most extreme absence of commuting. ${ }^{31}$ The LLPL volumes also make multiple mentions of workshops adjacent to or very nearby workers' residences, and to neighbourhoods of specific groups of workers, such as dock labourers, being located nearby their workplace.

The primary reason for the lack of inner-city commuting in the late-nineteenth century was almost certainly under-developed infrastructure. As can be seen in Table 2, the bus, tram, and Underground networks had fewer route miles and vehicle miles and slower travel speeds in the early-twentieth century than at the time of the New Survey. These supply-side issues were even greater in the 1890s, as most of the Underground lines had yet to be opened and buses and trams were still horse-drawn. Tables 2, 5 and 6 highlight an additional demand-side explanation for absence of commuting in the earlier period, namely income constraints. Table 5 shows that the returns from commuting are a function of

\footnotetext{
30 Booth (1902) refers to commuting by middle class workers, such as bankers and clerks (Booth 1902, vol. IX, p. 189). He also refers to working class travel in the context of outworkers picking up raw materials and dropping off finished products. However, these trips were only made on a weekly or bi-weekly basis.

${ }^{31}$ Booth (1902), Vol. IX, p. 204-5, Vol. IV, pp. 19, 41-42, 60, 71, 73, 79, 117, 149, 160-1, 174, 204, $278,295$.
} 
earnings, which were substantially lower in the 1890s than circa 1930. ${ }^{32}$ Table 2 shows that the real monetary cost of travel was considerably higher in the first decade of the twentieth century than in 1930 . It is likely that costs in the $1890 \mathrm{~s}$ were higher still. The combination of lower income, lower returns to commuting, and higher cost of public transport suggests that a much higher proportion of workers in the 1890s would have faced income constraints than was the case in 1930.

Tables 3 and 5 and the discussion from Booth (1902) can be used to estimate additional earnings due to increased commuting distance between 1890 and 1930 . Based on the discussion of co-location of residences and workplace and on the absence of discussion of longer commutes in Booth (1902), we believe that 200-500 meters was a plausible average one-way commute in the 1890s. Using the 1930 distances shown in Table 3, this implies an increased commuting distance 2.5-3.0 kilometres each way or 25-36 kilometres per week. Using the estimated returns from Table 5, column 1, this increased distance would imply an increase in earnings of about 5 to 6 percent, or about 18-36 percent of the real weekly earnings increase for the working class over this period of time. The lower end of these figures is similar to Leunig's (2006) finding that social savings from railways accounts for about one sixth of economy-wide productivity growth during latenineteenth and early-twentieth centuries. ${ }^{33}$

\footnotetext{
32 Lewellyn-Smith (1930a, p. 19) states that the real weekly earnings of working-class Londoners increased by about 20 percent between 1890 and 1928. After adjusting for the decline in the workweek and making the comparison between like-for-like workers, he concludes that the real hourly increase was about a third. This is very similar to other estimates of real earnings. For example, Clark (2020) calculates real earnings increase of 35.6 percent for the entire UK over the period 1895-1930.

${ }^{33}$ Increased commuting also had an important impact on time use. The 200-500 meter walk typical of the 1890s would have taken perhaps 3-7.5 minutes, whereas a 3 kilometre bus trip typical of 1930 would likely have taken about 9 minutes plus another 10-15 minutes walking at either end and waiting for the bus. Assuming a five and a half or six-day work week, there would have been about four hours weekly difference in the typical commuting times between the 1890s and 1930s.
} 


\section{Discussion - Commuting and Quality of Life}

This research provides important new insights to broader historical debates about improvements in the quality of life from the mid-nineteenth century onwards. Economic historians have long debated the broader implications of urbanization during the period of the Industrial Revolution (1780-1850). Urbanization led to higher productivity and incomes but also to crowding externalities, most notably reduced health due to the spread of waterborne and airborne diseases. ${ }^{34}$ Although extensively surveying this literature is beyond the scope of this paper, we note that this discussion rarely extends to the period beyond the mid-nineteenth century. It is generally recognized that increased income, improvements in health, and reduced hours of work resulted in marked improvements in quality of life in the late-nineteenth and particularly the early-twentieth centuries. By the middle of the twentieth century, per capita income was substantially higher than prior to the turn of the century (Crafts 1997; Clark 2005) and overall mortality rates in urban areas had declined to very similar levels as in rural areas (Szreter and Hardy 2001; Chapman 2019).

The role of transport in the improvement of urban quality from life from the midnineteenth century onwards has been largely overlooked. As far as we are aware, the literature has not previously explored the link between the improvement of commuter networks and productivity gains in the early-twentieth century. Similarly, improvements in health have generally been attributed to greater availability of fresh foods, better medical care, and improvements sanitation, rather than improvements in transport networks (Chapman 2019; Horrell 2000). Chapman (2019, p. 240) dismisses any link between public transport and urban health outright, stating, "There were also some spending items which would not have contributed to mortality declines including ... tram systems." However, our results suggest that improvements in public transport made two distinct and

\footnotetext{
34 "Optimists" have argued that the quality of life increased during the industrial revolution due to higher incomes (Lindert and Williamson 1983; Clark 2005). "Pessimists" have argued that income growth has been overstated (Feinstein 1998; Horrell and Humphries 1992, Allen 2009); that increases in income were due to longer hours of work (Voth 1998); and that urbanization contributed to declining health (Komlos 1998; Chapman 2019).
} 
important contributions to improvements in health and thus quality of life. First, commuting went in parallel with reduced crowding and the associated health externalities in the central areas by removing the need for co-location of residence and employment. Second, as shown in Section VI, commuting increased incomes and this likely had flow-on effects for health.

Census figures show that, although the population of the Metropolis continued to increase through to the NSLLL survey time, crowding in the wealthier central boroughs peaked in the mid- to late-nineteenth century. ${ }^{35}$ Crowding in the predominantly working-class central and middle boroughs peaked in the earlytwentieth century. ${ }^{36}$ While crowding remained a problem in 1930, the companion volumes of the NSLLL note that it was much less serious than it had been forty years earlier (Llewellyn-Smith 1930b; Ponsonby and Ruck 1930). The simultaneous declining population of inner London, increasing population of outer London, and increasing employment in the City suggests the importance of commuting. Rail was the only fully developed public transport network prior to the twentieth century and thus was primarily responsible for the initial outmigration and reduced crowding in the more prosperous central areas (Hebblich, et. al 2020). The construction of the Underground network and expansion and motorization of the bus and tram networks in the early twentieth century coincides with the population peak and subsequent decline in the workingclass inner-city areas.

The New Survey data provides direct evidence that commuting went hand-in-hand with reduced inner-city crowding. Approximately 58 percent of workers in the sample worked outside their borough of residence. Approximately 60 percent

\footnotetext{
35 The central boroughs in question and the Census year with the peak population are City of London (1851), Finsbury (1851), Holborn (1851), Shoreditch (1861), St Pancras (1891), St Marylebone (1851), Westminster (1851), and Bermondsey (1891). UK Census statistics show that the population of the inner ring declined from its peak of 1,671,000 in 1891 to 1,319,000 in 1931 . 36 The boroughs which reached a population peak in the 1901 Census were Bethnal Green, Stepney, Southwark, Islington, Paddington, Chelsea, Kensington, Lambeth, and Poplar. Battersea and Hackney peaked in 1911. Except for Chelsea and Kensington, all of these boroughs were predominantly working-class. The population of the middle ring declined slightly from its peak of $1,201,000$ in 1901 to $1,174,000$ in 1931.
} 
commuted regularly using public transport. ${ }^{37}$ There was a substantial net inflow to the central areas, (Figures 3 and 4). As can be seen in Table 1, workplace density in 1930 was higher than residential density, and much higher for the most densely concentrated industries. The most densely concentrated industries also typically had the longest average commutes. ${ }^{38}$ Thus, in the absence of public transport networks and widespread commuting it is likely that crowding circa 1930 would have been considerably greater than was actually the case.

The second mechanism by which commuting likely improved urban health and overall quality of life was through increased income, as shown in Section VI. Higher income contributed directly to improved quality of life. It also could be used to "buy" health through improvements in nutrition, medical care, or housing. The New Survey data do not contain any information on expenditures on food or medical care. However, it is likely that both were normal goods and thus some of the higher income from commuting would have been spent on these goods.

The impact of commuting on housing consumption can be estimated using hedonic regressions on weekly rents, and dwelling characteristics from the New Survey data. This is shown in Table 7. We begin with a parsimonious specification including only centrality and demographic characteristics of the head of household. We then add dwelling characteristics (number of bedrooms, kitchens, parlours, sculleries, bathrooms, pantries, outdoor spaces, and shared spaces) and centrality as independent variables. Additional specifications include dummy variables for shared household amenities, dummy variables for missing household amenities, and adding borough dummies.

\footnotetext{
37 Because transport expenditures are missing for about 30 percent of the sample, we can not provide an exact figure for public transport usage. We obtain an approximate number by adding the number of workers who report positive transport expenditure $(18,374)$ and the number with missing transport expenditures who commuted over two reasonable walking distances, one crowflies kilometre $(5,160)$ or one crow-flies mile $(3,300)$.

38 The two industries with the highest spatial concentration, clerks/typists and printers/photographers, had fairly typical residential Herfindahl indexes of 0.043 and 0.035 , respectively. These industries also had the longest average commutes of those shown in Table 1 (4.90 and 4.40 kilometres, respectively). Across all industries in Table 1, the correlation between the Spatial Herfindahl Index and the average commuting distance is 0.67 .
} 
In the first column, the coefficient on centrality is significant and positive, but after controlling for dwelling characteristics it is significantly negative, suggesting that dwellings located further from the centre contained both more rooms and rooms with additional dedicated attributes. The coefficient on centrality in column 3 implies that each kilometre away from the nearest centre reduced rent by about $1 \mathrm{~d}$ per week, about 0.5 percent of average earnings or 1.9 percent of average rent. ${ }^{39}$ As public transport allowed workers to live further from the centre, this result implies that the estimated returns in Table 5 may understate the effect on workers' purchasing power.

In addition, commuting could have substantially contributed to reducing withinhousehold crowding, by allowing households to rent larger dwellings. The implied costs of an additional bedroom and bathroom, $27.2 \mathrm{~d}$ and $50.1 \mathrm{~d}$ per week, respectively from Table 7 (column 3), are similar to returns for commuting 2 or 4 kilometres, respectively, for a worker at the median sample income (Table 6).

\section{Conclusions}

In this paper we have used data from the New Survey of London Life and Labour to examine the impact of access to public transport and commuting on workingclass London labour markets, circa 1930. In contrast to the 1890s, when most working-class employment was within a few hundred meters of their residence, longer commutes were fairly common by 1930. This was facilitated by improvements in the public transportation networks, which in 1930 were faster, cheaper and had much better coverage than had been the case in the 1890s.

Much of the debate about the Industrial Revolution weighs the gains from higher wages and lower prices of manufactured good against the costs of urban externalities, largely due to crowding. The "commuting revolution" between 1890

\footnotetext{
39 The dependent variable is weekly rent in hundredths of pence Housing, of course, differed in terms of unobservable quality and this is not captured in Table 7. Llewellyn-Smith (1930b) notes that the central areas contained some of the worst slums, suggesting that Table 7 underestimates the quality-adjusted discount associated with moving away from the centre.
} 
and 1930 reduced crowding by breaking the requirement of co-location of residence and workplace. In 1890 most working-class employees worked within a few hundred meters of their residence, by 1930 a substantial majority commuted at least one kilometre. The average commute was slightly over three kilometres. Our results show that increased commuting had a direct effect on quality of life through increased earnings. Our estimates point to a return of about two percent for each kilometre commuted, which implies that increased commuting accounts for between a fifth and a third of increased working-class earnings between 1890 and 1930. 


\section{References}

Abernethy, Simon (2017). "Deceptive data? The role of the investigators in the New Survey of London Life and Labour 1928-32." Historical Methods A Journal of Quantitative and Interdisciplinary History, 50(1):1-15.

Aldred, Rachel (2014). "The commute." In Adey, P.; Bissell, D.; Hannam; K., Merriman; P. Sheller; M., eds. Routledge Handbook of Mobilities. (Abington: Routledge), pp. 450-9.

Allen, Robert (2009). "Engels' pause: technical change, capital accumulation, and inequality in the British industrial revolution." Explorations in Economic History, 46(4): 418-35.

Bhaskar, V. and To, Ted (1999). "Minimum wages for Ronald McDonald monopsonies: A theory of monopsonistic competition." Economic Journal, 109(455): 190-203.

Bhaskar, V.; Manning, Alan; and To, Ted (2002). "Oligopsony and monopsonistic competition in labour markets." Journal of Economic Perspectives, 16(2): 155-74.

Booth, Charles (1902). Life and Labour of the People of London. (London: Macmillan).

Chapman, Jonathan (2019). "The contribution of infrastructure investment to Britain's urban mortality decline, 1861-1900." Economic History Review, 72, 1 (2019): 233-59.

City of London $(1866,1881,1891,1911)$. Report of the Day Census. (London: Simpkin, Marshall, Hamilton, Kent \& Co.).

Clark, Gregory (2005). "The condition of the working class in England, 12092004." Journal of Political Economy, 113(6): 1307-40.

Clark, Gregory (2020). "What were the British earnings and prices then? (new series)." Measuring Worth, http://www.measuringworth.com/ukearncpi/ [Accessed 25/9/2020].

Crafts, Nicholas (1997). "The human development index and changes in standards of living: Some historical comparisons." European Review of Economic History, 1(3): 299-323.

Crafts, Nicholas and Leunig, Tim (2005). "The historical significance of transport for economic growth and productivity." Eddington Transport Study: Research Annexes Vol. 1.

Dyos, H. J. (1953). “Workmen's fares in south London, 1860 - 1914." Journal of Transport History, fs-1(1): 3-19.

Feinstein, Charles (1998). "Pessimism perpetuated: real wages and the standard of living in Britain during and after the Industrial Revolution." Journal of Economic History, 58(3): 625-58.

Gibbons, Stephen and Machin, Stephen (2006). "Transport and labour market linkages: empirical evidence, implications for policy and scope for further UK research.” Department of Transport.

Greater London Authority (2015). Characteristics of Commuters. (London: Greater London Authority).

Hatton, Timothy and Bailey, Roy (1998). "Poverty and the welfare state in interwar London." Oxford Economic Papers, 50(4): 574-606. 
Heblich, Stephan, Redding, Stephen, and Sturm, Daniel (2020). "The making of the modern metropolis: Evidence from London." The Quarterly Journal of Economics, 135(4): 2059-133.

Horrell, Sara (2000). "Living standards in Britain 1900-2000: women's century?" National Institute Economic Review, 172: 62-77

Horrell, Sara and Humphries, Jane (1992). "Old questions, new data, and alternative perspectives: families' living standards in the Industrial Revolution." Journal of Economic History, 52(4): 849-80.

Huberman, Michael and Minns, Christopher (2007). "The times they are not changin': Days and hours of work in Old and New Worlds, 1870-2000." Explorations in Economic History, 44(4): 538-67.

Johnson, Paul, Bailey, Roy, Baines, Dudley, Raspin, Anna, Hatton, Timothy (1999). New Survey of London Life and Labour, 1929-1931. [data collection]. 2nd Edition. UK Data Service. SN: 3758, http://doi.org/10.5255/UKDA-SN3758-1. https://beta.ukdataservice.ac.uk/datacatalogue/studies/study?id=3758 [Accessed 25/9/2020].

Kain, John (1962). "The journey-to-work as a determinant of residential location." Papers in Regional Science, 9(1): 137-60.

Komlos, John (1998). "Shrinking in a growing economy? The mystery of physical stature during the Industrial Revolution." Journal of Economic History, 58(3): 779-802.

Leunig, Tim (2006). "Time is money: a re-assessment of the passenger social savings from Victorian British railways." Journal of Economic History, 66(3): 635-73.

Lindert, P. H. and Williamson, J. G. (1983). "English workers' living standards during the Industrial Revolution: a new look." Economic History Review, 36(1): 1-25.

Llewellyn-Smith, Hubert (1930a). "Introduction". In Llewellyn-Smith, Hubert (ed.) The New Survey of London Life and Labour (London: P. S. King), pp. 157.

Llewellyn-Smith, Hubert (1930b). "House rents and overcrowding". In LlewellynSmith, Hubert (ed.) The New Survey of London Life and Labour (London: P. S. King), pp. 143-70.

London County Council (various years). London Statistics. (London: P. S. King and Son).

London School of Economics (2020). Charles Booth's London: Poverty Maps and Police Notebooks. https://booth.lse.ac.uk/map/14/-0.1174/51.5064/100/0 [accessed 13/9/2020].

London Transport Museum (2020). "London's transport history: A social history of London's public transport, 1829-2000."

https://web.archive.org/web/20070609023730/http://www.ltmuseum.co.uk/le arning/online_resources/ecobus_omnibus/pg/intro.htm [Accessed 25/9/2020].

Maddison, Angus (1964). Economic Growth in the West. (New York: Twentieth Century Fund).

Manning, Alan (2003a). Monopsony in Motion. (Princeton: Princeton University Press). 
Manning, Alan (2003b). "The Real Thin Theory: Monopsony in Modern Labour Markets",

Labour Economics, 10(2): 105-131.

Measuring Worth (2020). "Five ways to compute the relative value of a U.K. dollar amount, 1270 to present." https://www.measuringworth.com/calculators/ukcompare/

Mincer, Jacob (1958). "Investment in human capital and personal income distribution.” Journal of Political Economy, 66 (4): 281-302.

Mincer, Jacob (1974). Schooling, Experience and Earnings. New York: National Bureau of Economic Research.

Morgan, Mary, Bhullar, Inderbir, Wise, Sarah, Power, Anne, Garner, Katie, Reid, Aileen and Field, Jacob (2019). Charles Booth's London Poverty Maps. (London: Thames \& Hudson).

Mortensen, Dale and Pissarides, Christopher (1994). "Job creation and job destruction in the theory of unemployment." The Review of Economic Studies, 61(3): 397-415.

Munby, D. L. (1978). Inland Transport Statistics: Railways; Public Road Passenger Transport: London's Transport v. 1: Great Britain, 1900-70. (Oxford: Clarendon Press).

National Library of Scotland (2020). Side-by-Side Map Images. https://maps.nls.uk/ [Accessed 25/9/2020].

Orford, Scott, Dorling, Danny, Mitchell, Richard, Shaw, Mary and Davey Smith, George 2002. "Life and death of the people of London: a historical GIS of Charles Booth's inquiry." Health \& Place, 8(1): 25-35.

O'Regan, Katherine and Quigley, John (1993). "Family networks and youth access to jobs." Journal of Urban Economics, 34(2): 230-48.

Paul, Jonathan (2016). "High-resolution geological maps of central London, UK: Comparisons with the London Underground." Geoscience Frontiers, 7(2): 273-86.

Polasky, Janet (2010). Reforming urban labour: Routes to the city, roots in the country (Ithaca: Cornell University Press).

Ponsonby, G. and Ruck, S. K. (1930). "Travel and mobility". In Llewellyn-Smith, Hubert, eds. The New Survey of London Life and Labour. (London: P. S. King), pp. 171-99.

Prados de la Escosura, Leandro (2015). "World human development: 1870-2007." Review of Income and Wealth, 61(2): 220-47.

Redding, Stephen and Sturm, Daniel (2016). "Estimating neighborhood effects: Evidence from war-time destruction in London." Mimeo, London School of Economics.

Rees, Albert and Schultz, George (1970). Workers in an Urban Labour Market. (Chicago: University of Chicago Press).

Rogerson, Richard; Shimer, Robert; and Wright, Randall (2005). "Searchtheoretic models of the labour market: A survey." Journal of Economic Literature, 43(4): 959-88.

Rotemberg, Julio and Saloner, Garth (2000). "Competition and human capital accumulation: A theory of interregional specialization and trade." Regional Science and Urban Economics, 30(4): 373-404. 
Seltzer, Andrew (2020a). London Bus Map, 1931-32.

http://sharemap.org/ajseltzer1/london_bus_1931\#!webgl [accessed 25/9/2020].

Seltzer, Andrew (2020b). London Underground Map, 1931.

http://sharemap.org/ajseltzer1/underground_1\#!webgl [accessed 25/9/2020].

Seltzer, Andrew (2020c). London Train Map, 1931.

http://sharemap.org/ajseltzer1/London_Railways\#!webgl [accessed 25/9/2020].

Seltzer, Andrew (2020d). London Tram Map, 1931.

http://sharemap.org/ajseltzer1/trams_1\#!webgl [accessed 25/9/2020].

Streetmap (2020). https://www.streetmap.co.uk/ [accessed 25/9/2020].

Szreter, Simon and Hardy, Anne (2001). "Urban fertility and mortality patterns." In: Martin Daunton, ed. The Cambridge Urban History of Britain. (Cambridge: Cambridge University Press), pp. 629-72.

van Ommeren, Jos, Rietveld, Piet, and Nijkamp, Peter (1997). "Commuting: in search of jobs and residences." Journal of Urban Economics, 42(3): 402-21.

Voth, Hans-Joachim (1998). "Time and work in eighteenth-century London." Journal of Economic History, 58(1): 29-58.

Wardman, Mark (1998). "The value of travel time: A review of British evidence." Journal of Transport Economics and Policy, 32(3): 285-316.

Zamparini, Luca and Reggiani, Aura (2007). "Meta-analysis and the value of travel time savings: a transatlantic perspective in passenger transport." Networks and Spatial Economics, 7(4): 377-96. 
Table 1. Spatial Herfindahl Indexes by Industry

\begin{tabular}{|l|l|l|l|}
\hline Industry & Modal Borough & $\mathrm{N}$ & $\mathrm{H}$ \\
\hline & & & \\
\hline Transport \& communications & City of London & 5,821 & 0.042 \\
\hline Personal service & Westminster & 3,835 & 0.046 \\
\hline Makers of textile goods & Stepney & 3,154 & 0.067 \\
\hline Commerce, finance, insurance & City of London & 3,053 & 0.033 \\
\hline Metal workers & Woolwich & 2,644 & 0.039 \\
\hline Clerks, typists & City of London & 1,911 & 0.116 \\
\hline Warehousemen, storekeepers, packers & City of London & 1,656 & 0.066 \\
\hline Wood and furniture & Bethnal Green & 1,612 & 0.041 \\
\hline Builders, bricklayers, stone \& contractors & City of London & 1,234 & 0.034 \\
\hline Foods, drinks \& tobacco & West Ham & 1,100 & 0.044 \\
\hline Painters and decorators & Hackney & 838 & 0.034 \\
\hline Printers and photographers & City of London & 822 & 0.148 \\
\hline Electrical apparatus \& electricians & Woolwich & 761 & 0.060 \\
\hline & & & \\
\hline All employment & City of London & 33,566 & 0.038 \\
\hline & & & \\
\hline Residences & Islington & 94,136 & 0.035 \\
\hline
\end{tabular}

Sources: Johnson, et. al. (1999) and authors' calculations. 
Table 2. Public Transportation Statistics for 1900-07, 1913, and 1929

\begin{tabular}{|c|c|c|c|c|}
\hline & & 1900-07 & 1913 & 1929 \\
\hline \multirow{5}{*}{$\begin{array}{l}\text { Local and } \\
\text { Underground } \\
\text { railways }\end{array}$} & Route miles & 95.2 & 110.6 & 120.6 \\
\hline & Train miles $(1,000,000 \mathrm{~s})$ & 5.01 & 18.45 & 24.13 \\
\hline & Passengers $(1,000,000 \mathrm{~s})$ & 214.5 & 474.7 & 648.8 \\
\hline & $\begin{array}{l}\text { Average fare per mile } \\
\text { (in } 1930 \text { pence) }\end{array}$ & 1.143 & 0.989 & 0.790 \\
\hline & $\begin{array}{l}\begin{array}{l}\text { Average scheduled speed } \\
\text { (in kilometres per hour) }\end{array} \\
\end{array}$ & 24.1 & 28.8 & 31.1 \\
\hline \multirow{4}{*}{$\begin{array}{l}\text { Mainline } \\
\text { railways }\end{array}$} & Route miles & 561.2 & 558.2 & 534.1 \\
\hline & Daily trains & 2097 & $\mathrm{NA}$ & 2799 \\
\hline & $\begin{array}{l}\text { Average scheduled speed } \\
\text { (in kilometres per hour) }\end{array}$ & 32.35 & NA & NA \\
\hline & Passengers $(1,000,000 \mathrm{~s})$ & 233 & 250 & 415 \\
\hline \multirow{6}{*}{ Buses } & Route miles & 300 & 467 & 1,170 \\
\hline & Car miles $(1,000,000 \mathrm{~s})$ & 42.0 & 110.0 & 215.7 \\
\hline & $\begin{array}{l}\text { Average scheduled speed } \\
\text { (in kilometres per hour) }\end{array}$ & 8.0 & 13.7 & 15.3 \\
\hline & Passengers $(1,000,000 \mathrm{~s})$ & 264.5 & 735.7 & $1,912.1$ \\
\hline & $\begin{array}{l}\text { Average fare per mile } \\
\text { (in } 1930 \text { pence) }\end{array}$ & 1.879 & 1.061 & 0.960 \\
\hline & Average seats per vehicle & 23 & 34 & 50 \\
\hline \multirow{6}{*}{ Tramways } & Miles of roadway & 221.7 & 350.3 & 345.5 \\
\hline & \begin{tabular}{|l} 
Car miles $(1,000,000 \mathrm{~s})$ \\
\end{tabular} & 47.9 & 95.9 & 104.3 \\
\hline & $\begin{array}{l}\text { Average scheduled speed } \\
\text { (in kilometres per hour) }\end{array}$ & N.A. & 14.2 & 16.1 \\
\hline & Passengers $(1,000,000 \mathrm{~s})$ & 340.2 & 812.1 & $1,076.3$ \\
\hline & $\begin{array}{l}\text { Average fare per mile } \\
\text { (in } 1930 \text { pence) }\end{array}$ & 1.062 & 0.899 & 0.680 \\
\hline & Average seats per vehicle & 38 & 67 & 67 \\
\hline
\end{tabular}

Notes: The figures for the first column are from 1900, 1905, 1906, and 1907. See Ponsonby and Ruck (1930), p. 194 for details. Figures for fares are converted into 1930 prices using O'Donoghue, et. al. (2004). The reported scheduled speed for the London Underground is for the Metropolitan and District Line.

Sources: Ponsonby and Ruck (1930), p. 194 and Munby (1978), p. 537. 
Table 3. Summary Statistics on Commuting

\begin{tabular}{|c|c|}
\hline & $\begin{array}{l}\text { Mean (standard } \\
\text { deviation) }\end{array}$ \\
\hline Distance from home to nearest train station & $0.64(0.35)$ \\
\hline Distance from home to nearest Underground station & $1.17(1.21)$ \\
\hline Distance from home to nearest bus stop & $0.20(0.16)$ \\
\hline Distance from home to nearest tram stop & $0.35(0.31)$ \\
\hline Distance from workplace to nearest train station & $0.61(0.41)$ \\
\hline Distance from workplace to nearest Underground station & $0.97(1.21)$ \\
\hline Distance from workplace to nearest bus stop & $0.16(0.19)$ \\
\hline Distance from workplace to nearest tram stop & $0.41(0.42)$ \\
\hline Distance from home to work & $3.05(3.35)$ \\
\hline $10^{\text {th }}$ percentile & 0.40 \\
\hline $25^{\text {th }}$ percentile & 0.85 \\
\hline Median & 1.94 \\
\hline $75^{\text {th }}$ percentile & 4.16 \\
\hline 90, percentile & 7.25 \\
\hline 95 ${ }^{\text {th }}$ percentile & 9.38 \\
\hline 99th percentile & 14.39 \\
\hline Heads of household & $3.08(3.47)$ \\
\hline Others & $3.02(3.21)$ \\
\hline Male & $3.21(3.55)$ \\
\hline Female & $2.69(2.82)$ \\
\hline Skill Category $=$ professional & $6.31(6.47)$ \\
\hline Skill Category $=$ middling & $4.11(4.48)$ \\
\hline Skill Category $=$ skilled & $3.42(3.62)$ \\
\hline Skill Category $=$ semi-skilled & $2.60(2.83)$ \\
\hline Skill Category $=$ unskilled & $2.73(3.09)$ \\
\hline \multicolumn{2}{|l|}{ Direction of Commute } \\
\hline Commutes inwards & $37.9 \%$ \\
\hline Commutes outwards & $16.0 \%$ \\
\hline Works locally, does not commute & $29.4 \%$ \\
\hline Commutes across & $16.7 \%$ \\
\hline
\end{tabular}

Notes: Standard deviation are shown in parentheses for continuous variables. Sample sizes: 49,361 with an earner number (used to estimate distances from home to public transportation), 34,972 with an identifiable workplace. Distances from workplace to public transport is only reported for workers employed in the New Survey area.

Sources: Johnson, et. al. (1999) and authors' calculations. 
Table 4: Distance Effects on Labour Force Participation

\begin{tabular}{|c|c|c|c|c|c|c|c|}
\hline & $(1)$ & $(2)$ & (3) & (4) & (5) & (6) & $(7)$ \\
\hline & $\begin{array}{c}\text { Hours }>0: \\
\text { Probit }\end{array}$ & $\begin{array}{c}\text { In Work: } \\
\text { Probit }\end{array}$ & $\begin{array}{l}\text { Dist. to } \\
\text { Work: } \\
\text { OLS }\end{array}$ & $\begin{array}{l}\text { Dist. to } \\
\text { Work: } \\
\text { Heckman }\end{array}$ & $\begin{array}{c}\text { Tran. } \\
\text { Costs=0: } \\
\text { Probit }\end{array}$ & $\begin{array}{c}\text { Dist. to } \\
\text { work }<1 \mathrm{Km}: \\
\text { Probit }\end{array}$ & $\begin{array}{c}\text { Dist. to } \\
\text { work }>3.2 \mathrm{Km}: \\
\text { Probit }\end{array}$ \\
\hline Distance-Train & $\begin{array}{c}0.016^{*} \\
(0.006)\end{array}$ & $\begin{array}{c}0.006 \\
(0.006) \\
\end{array}$ & $\begin{array}{c}-0.025 \\
(0.124) \\
\end{array}$ & $\begin{array}{c}-0.010 \\
(0.116) \\
\end{array}$ & $\begin{array}{c}0.022 \\
(0.012) \\
\end{array}$ & $\begin{array}{c}-0.003 \\
(0.010) \\
\end{array}$ & $\begin{array}{l}-0.008 \\
(0.010) \\
\end{array}$ \\
\hline Distance-Tram & $\begin{array}{c}0.002 \\
(0.007) \\
\end{array}$ & $\begin{array}{c}0.002 \\
(0.007) \\
\end{array}$ & $\begin{array}{c}0.185 \\
(0.133) \\
\end{array}$ & $\begin{array}{c}0.180 \\
(0.144) \\
\end{array}$ & $\begin{array}{c}-0.020 \\
(0.015) \\
\end{array}$ & $\begin{array}{l}-0.059^{*} \\
(0.012)\end{array}$ & $\begin{array}{c}0.010 \\
(0.012) \\
\end{array}$ \\
\hline Distance-Bus & $\begin{array}{c}-0.017 \\
(0.012) \\
\end{array}$ & $\begin{array}{l}-0.030^{*} \\
(0.011)\end{array}$ & $\begin{array}{c}-0.174 \\
(0.232) \\
\end{array}$ & $\begin{array}{c}-0.188 \\
(0.235) \\
\end{array}$ & $\begin{array}{c}0.029 \\
(0.024) \\
\end{array}$ & $\begin{array}{c}-0.006 \\
(0.020) \\
\end{array}$ & $\begin{array}{l}-0.010 \\
(0.020) \\
\end{array}$ \\
\hline
\end{tabular}

Notes: The sample consists of individuals aged 14 or more who were related to the head of household. Robust Standard errors in brackets. * $=$ significant at 5\%. Marginal effects evaluated at sample means reported for probit estimates. Pseudo $\mathrm{R}^{2}$ reported for all probits. The Heckman regression in column 4 uses the probit on reporting positive hours in the previous week (column 1) as the first stage. The difference in the sample means of the dep endent variable between columns 1 and 2 is mainly driven by more observations with missing hours among self-employed workers, who typically commuted shorter distances. This may help explain differences in the estimates between the two specifications. See Appendix IV, Tables A.IV.1 and A.IV.2 for additional results.

Sources: Johnson, et. al. (1999) and authors' calculations. 
Table 5. Regressions on the Distance Effects on Log Weekly Earnings

\begin{tabular}{|l|c|c|c|c|c|c|}
\hline & $(1)$ & $(2)$ & $(3)$ & $(4)$ & $(5)$ & $(5)$ \\
\hline & $\begin{array}{c}\text { Related } \\
\text { to Head: } \\
\text { OLS }\end{array}$ & $\begin{array}{c}\text { Related } \\
\text { to Head: } \\
\text { Heckman }\end{array}$ & $\begin{array}{c}\text { Related to } \\
\text { Head \& } \\
\text { Age<25 }\end{array}$ & $\begin{array}{c}\text { Children } \\
\text { of Head \& } \\
\text { Age<25 }\end{array}$ & All & $\begin{array}{c}\text { All: HH } \\
\text { Fixed } \\
\text { Effects }\end{array}$ \\
\hline Distance & $2.577^{*}$ & $2.574^{*}$ & $2.144^{*}$ & $2.017^{*}$ & $2.185^{*}$ & $2.134^{*}$ \\
& $(0.233)$ & $(0.231)$ & $(0.244)$ & $(0.247)$ & $(0.167)$ & $(0.229)$ \\
\hline Distance & $-0.0489^{*}$ & $-0.0490^{*}$ & $-0.0486^{*}$ & $-0.0448^{*}$ & $-0.0605^{*}$ & $-0.0551^{*}$ \\
squared & $(0.0138)$ & $(0.0137)$ & $(0.0148)$ & $(0.015)$ & $(0.0113)$ & $(0.0125)$ \\
\hline Home & -0.062 & -0.066 & -0.335 & -0.156 & $1.105^{*}$ & \\
Centrality & $(0.355)$ & $(0.354)$ & $(0.351)$ & $(0.357)$ & $(0.236)$ & \\
\hline Home-Train & 1.659 & 1.510 & $2.133^{*}$ & $2.601^{*}$ & 0.736 & \\
& $(0.978)$ & $(0.977)$ & $(0.957)$ & $(0.976)$ & $(0.644)$ & \\
\hline Home- & 0.768 & 0.763 & 0.701 & 0.792 & -0.221 & \\
Underground & $(0.614)$ & $(0.612)$ & $(0.615)$ & $(0.620)$ & $(0.384)$ & \\
\hline Home-Tram & 2.405 & 2.380 & 1.098 & 1.505 & 1.380 & \\
& $(1.255)$ & $(1.250)$ & $(1.222)$ & $(1.236)$ & $(0.773)$ & \\
\hline Home-Bus & -2.882 & -2.826 & -1.687 & -1.995 & -1.620 & \\
& $(2.082)$ & $(2.074)$ & $(2.050)$ & $(2.074)$ & $(1.261)$ & \\
\hline Work & -0.139 & -0.136 & -0.213 & -0.040 & 0.194 & 0.242 \\
Centrality & $(0.348)$ & $(0.347)$ & $(0.341)$ & $(0.345)$ & $(0.230)$ & $(0.369)$ \\
\hline Work-Train & -0.533 & -0.529 & -1.459 & -1.171 & 0.513 & -0.111 \\
& $(0.943)$ & $(0.938)$ & $(0.908)$ & $(0.914)$ & $(0.566)$ & $(0.911)$ \\
\hline Work- & 0.929 & 0.930 & 0.955 & 0.961 & 0.363 & -0.025 \\
Underground & $(0.483)$ & $(0.481)$ & $(0.539)$ & $(0.543)$ & $(0.298)$ & $(0.558)$ \\
\hline Work-Tram & 0.773 & 0.774 & 0.444 & 0.213 & 0.552 & -0.962 \\
& $(0.804)$ & $(0.800)$ & $(0.832)$ & $(0.861)$ & $(0.493)$ & $(0.816)$ \\
\hline Work-Bus & 0.229 & 0.227 & 0.980 & 0.716 & 0.241 & $3.887^{*}$ \\
& $(1.120)$ & $(1.112)$ & $(1.302)$ & $(1.296)$ & $(0.707)$ & $(1.195)$ \\
\hline Observations & 15,436 & 15,436 & 11,997 & 11,354 & 31,668 & 31,668 \\
\hline R-squared & 0.572 & & 0.632 & 0.645 & 0.687 & 0.891 \\
\hline F statistic & 173.123 & & & & 601.849 & 370.387 \\
\hline
\end{tabular}

Notes: The dependent variable is the natural log of earnings (in hundredths of pence) in the previous week. All regression coefficients and standard errors multiplied by 100. The first stage controls in the Heckman regressions are as in Table 4, column 1. Household characteristics are omitted in the household fixed effects specification. Robust standard errors in brackets. * indicates significance at a 5\% level. See Appendix IV, Tables A.IV.3, A.IV.4, A.IV.5 for additional results. Sources: Johnson, et. al. (1999) and authors' calculations. 
Table 6. Costs and Returns of Commuting

\begin{tabular}{|c|c|c|c|c|c|c|c|c|c|c|c|}
\hline $\begin{array}{l}\text { Crow- } \\
\text { flies dist. } \\
\text { (mtrs) }\end{array}$ & $\begin{array}{l}\text { Trans. } \\
\text { mode }\end{array}$ & $\begin{array}{l}\text { Dist. } \\
\text { walked }\end{array}$ & $\begin{array}{l}\text { Dist. } \\
\text { public } \\
\text { trans. }\end{array}$ & $\begin{array}{l}\text { Walk } \\
\text { time } \\
\text { (mins) }\end{array}$ & $\begin{array}{l}\text { public } \\
\text { trans. time } \\
\text { (mins) } \\
\end{array}$ & $\begin{array}{l}\text { implied } \\
\text { return } \\
\left(10^{\text {th }} \text { perc. }\right) \\
\end{array}$ & $\begin{array}{l}\text { implied } \\
\text { return } \\
\left(25^{\text {th }} \text { perc. }\right) \\
\end{array}$ & $\begin{array}{l}\text { implied } \\
\text { return } \\
\text { (median) }\end{array}$ & $\begin{array}{l}\text { Monetary } \\
\text { cost }(d)\end{array}$ & $\begin{array}{l}\text { implied time } \\
\text { cost, } 10^{\text {th }} \\
\text { perc. (d) }\end{array}$ & $\begin{array}{l}\text { implied } \\
\text { time cost, } \\
\text { median }(\mathrm{d})\end{array}$ \\
\hline 500 & Walk & 625 & 0 & 9.38 & 0 & 2.31 & 3.85 & 7.49 & 0 & 3.52 & 11.40 \\
\hline 1,000 & Walk & 1250 & 0 & 18.75 & 0 & 4.61 & 7.68 & 14.94 & 0 & 7.03 & 22.79 \\
\hline 2,000 & Bus & 300 & 2,200 & 4.5 & 8.62 & 9.15 & 15.25 & 29.66 & $6-12$ & 6.50 & 21.08 \\
\hline 2,000 & Tram & 300 & 2,200 & 4.5 & 8.20 & 9.15 & 15.25 & 29.66 & $6-12$ & 6.36 & 20.60 \\
\hline 4,000 & $\mathrm{UG}$ & 600 & 4,400 & 9 & 7.83 & 17.99 & 29.98 & 58.31 & $12-24$ & 9.05 & 29.32 \\
\hline 8,000 & $\mathrm{UG}$ & 600 & 8,800 & 9 & 15.66 & 34.39 & 57.32 & 111.48 & $18-30$ & 11.72 & 37.98 \\
\hline 8,000 & Train & 600 & 8,800 & 9 & 15.08 & 34.39 & 57.32 & 111.48 & $18-30$ & 11.52 & 37.33 \\
\hline 16,000 & Train & 600 & 17,600 & 9 & 30.17 & 59.85 & 99.75 & 194.02 & $30-36$ & 16.66 & 54.01 \\
\hline
\end{tabular}

Notes: The tenth, twenty fifth, and fiftieth percentile of weekly earnings were 180d, 300d, and 583.5d, respectively.

Sources: Ponsonby and Ruck (1930); Johnson, et. al. (1999); and authors' calculations. 
Table 7: Distance Effects on Rents

\begin{tabular}{|c|c|c|c|c|c|}
\hline & (1) & (2) & (3) & (4) & (5) \\
\hline Centrality & $\begin{array}{l}447.2^{*} \\
(67.7)\end{array}$ & $\begin{array}{l}-266.5^{*} \\
(83.6)\end{array}$ & $\begin{array}{l}-311.5^{*} \\
(85.7)\end{array}$ & $\begin{array}{l}-321.2^{*} \\
(88.1)\end{array}$ & $\begin{array}{l}-510.4^{*} \\
(202.9)\end{array}$ \\
\hline No. Bedrooms & & $\begin{array}{l}2674.9^{*} \\
(319.5)\end{array}$ & $\begin{array}{l}2721.1^{*} \\
(319.6)\end{array}$ & $\begin{array}{l}2724.4^{*} \\
(321.9)\end{array}$ & $\begin{array}{l}2743.9^{*} \\
(318.3)\end{array}$ \\
\hline Kitchen & & $\begin{array}{l}3836.1^{*} \\
(399.3)\end{array}$ & $\begin{array}{l}3845.0^{*} \\
(412.7)\end{array}$ & $\begin{array}{l}4114.3^{*} \\
(302.4)\end{array}$ & $\begin{array}{l}4208.9^{*} \\
(336.4)\end{array}$ \\
\hline Parlour & & $\begin{array}{l}4950.7^{*} \\
(341.1)\end{array}$ & $\begin{array}{l}4814.6^{*} \\
(360.7)\end{array}$ & $\begin{array}{l}4567.0^{*} \\
(397.5)\end{array}$ & $\begin{array}{l}4423.8^{*} \\
(414.2)\end{array}$ \\
\hline Scullery & & $\begin{array}{l}1511.7^{*} \\
(444.1)\end{array}$ & $\begin{array}{l}1564.0^{*} \\
(465.6) \\
\end{array}$ & $\begin{array}{l}1402.0^{*} \\
(495.0)\end{array}$ & $\begin{array}{l}1879.3^{*} \\
(520.4)\end{array}$ \\
\hline Pantry & & $\begin{array}{l}2333.5^{*} \\
(965.8)\end{array}$ & $\begin{array}{l}2202.4^{*} \\
(971.0)\end{array}$ & $\begin{array}{l}2265.7^{*} \\
(944.8)\end{array}$ & $\begin{array}{l}2079.8^{*} \\
(977.4)\end{array}$ \\
\hline Bathroom & & $\begin{array}{l}4705.0^{*} \\
(1434.5)\end{array}$ & $\begin{array}{l}5013.5^{*} \\
(1436.7) \\
\end{array}$ & $\begin{array}{l}4973.3^{*} \\
(1415.4) \\
\end{array}$ & $\begin{array}{l}4852.2^{*} \\
(1532.7) \\
\end{array}$ \\
\hline Backyard & & $\begin{array}{c}911.8 \\
(563.1) \\
\end{array}$ & $\begin{array}{l}1033.0 \\
(580.7) \\
\end{array}$ & $\begin{array}{c}963.5 \\
(632.9) \\
\end{array}$ & $\begin{array}{l}1252.5 \\
(662.5) \\
\end{array}$ \\
\hline Garden & & $\begin{array}{l}1778.8^{*} \\
(576.8)\end{array}$ & $\begin{array}{l}1914.0^{*} \\
(608.0)\end{array}$ & $\begin{array}{l}1884.6^{*} \\
(632.4)\end{array}$ & $\begin{array}{r}2489.6^{*} \\
(680.8)\end{array}$ \\
\hline Constant & $\begin{array}{c}-17.3 \\
(2788.8) \\
\end{array}$ & $\begin{array}{l}11624.7^{*} \\
(2869.8)\end{array}$ & $\begin{array}{l}11386.2^{*} \\
(2885.3)\end{array}$ & $\begin{array}{l}11535.4^{*} \\
(2887.3)\end{array}$ & $\begin{array}{l}8071.7^{*} \\
(3049.8) \\
\end{array}$ \\
\hline Demographic controls & YES & YES & YES & YES & YES \\
\hline Shared amenities & $\mathrm{NO}$ & $\mathrm{NO}$ & YES & YES & YES \\
\hline $\begin{array}{l}\text { Dummy for missing } \\
\text { amenities }\end{array}$ & $\mathrm{NO}$ & $\mathrm{NO}$ & $\mathrm{NO}$ & YES & YES \\
\hline Borough Dummies & $\mathrm{NO}$ & $\mathrm{NO}$ & $\mathrm{NO}$ & $\mathrm{NO}$ & YES \\
\hline Observations & 15,087 & 15,087 & 15,087 & 15,087 & 15,087 \\
\hline R-squared & 0.019 & 0.070 & 0.071 & 0.072 & 0.082 \\
\hline F statistic & $22.0^{*}$ & $97.3^{*}$ & $99.0^{*}$ & $100.9^{*}$ & $94.7^{*}$ \\
\hline
\end{tabular}

Notes: The dependent variable is weekly rent in hundredths of pence. The sample is heads of households, as this ensures one observation per dwelling. The demographic controls are age, age $^{2}$, age not reported, sex, born in England, born in London, born in same borough as current residence, and born in an adjacent borough to current borough of residence. Amenities were often shared across households (e.g. bathrooms were shared between apartments) and the shared amenities specification contains an additional dummy variable for each of the amenities listed above. Specifications without dummies for missing amenities set the value of any missing amenity to zero. * indicates significance at a 5\% level.

Source: Johnson, et. al. (1999); Authors' calculations. 
Figure 1. Commuting, Labour Force Participation, and Earnings

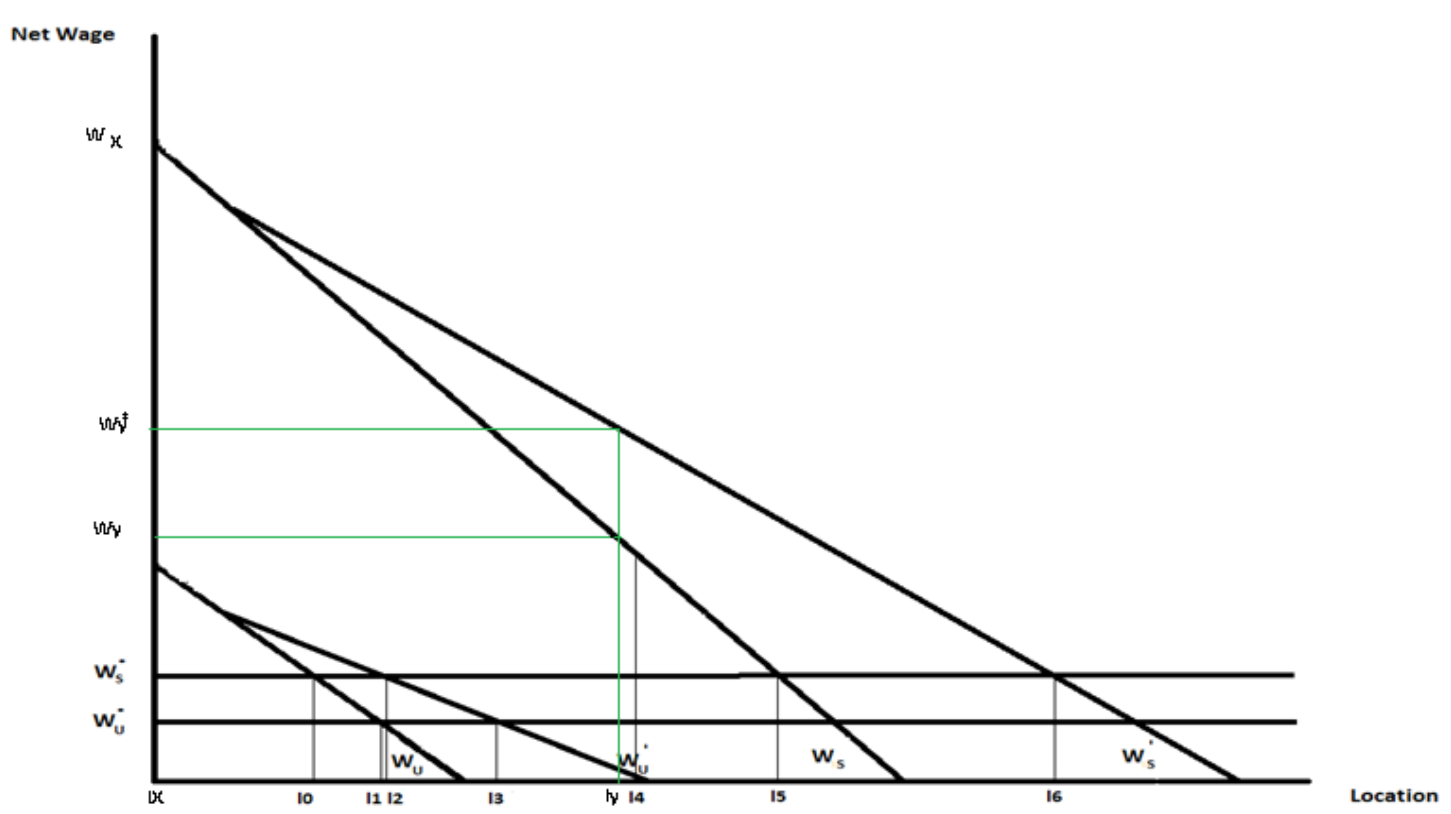




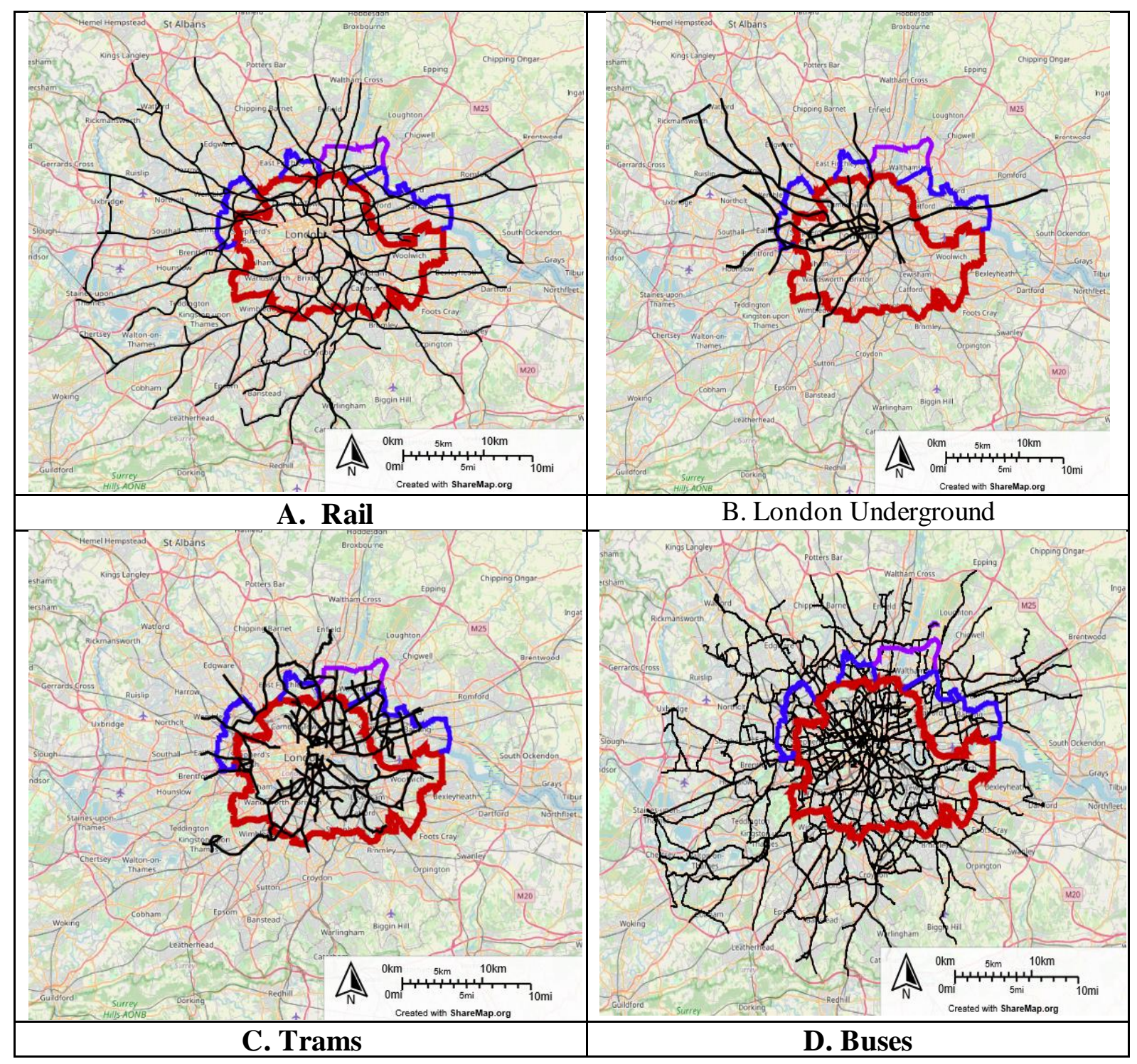

Notes: The maps show the transport networks (circa 1931) within the Greater London area (inside the modern ring road, the M25). The border of the County of London and the New Survey catchment area are shown to provide scale. Scalable versions of these maps can be found at Seltzer (2020a, 2020b, 2020c, 2020d).

Sources: National Library of Scotland, Map Images, https://maps.nls.uk/geo/explore/side-by-side; Omnibus Society, Motor Omnibus Routes in London, vol 10a, 1930-31; http://sharemap.org/public/Trams in London\#!webgl; Underground, https://londonist.com/2016/05/the-history-of-the-tube-map. 
Figure 3. Commuting Destinations of Residents of Four Boroughs

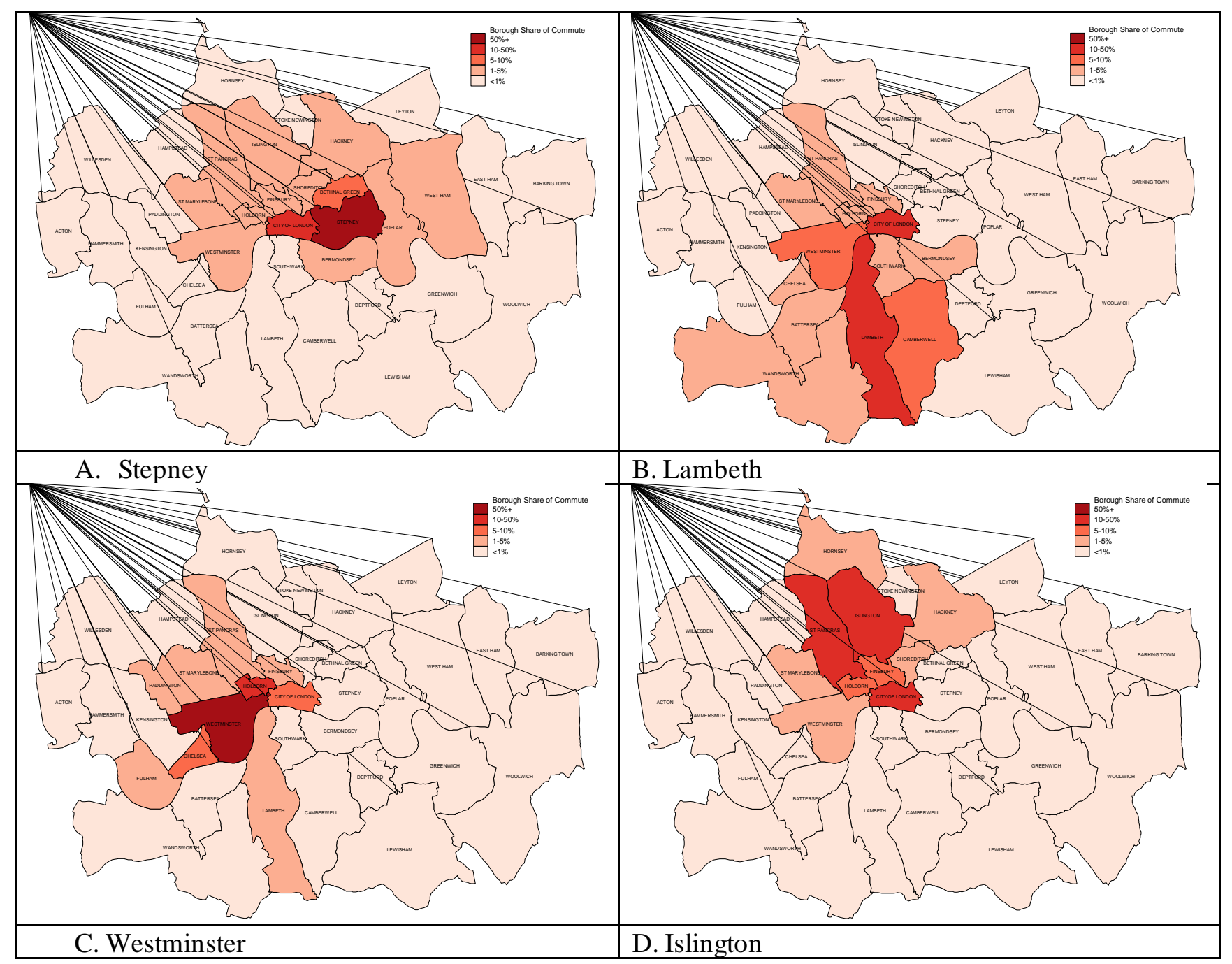

Sources: Johnson, et. al. (1999); Authors' calculations. 
Figure 4. Net Commuting Flows by Borough of Residence

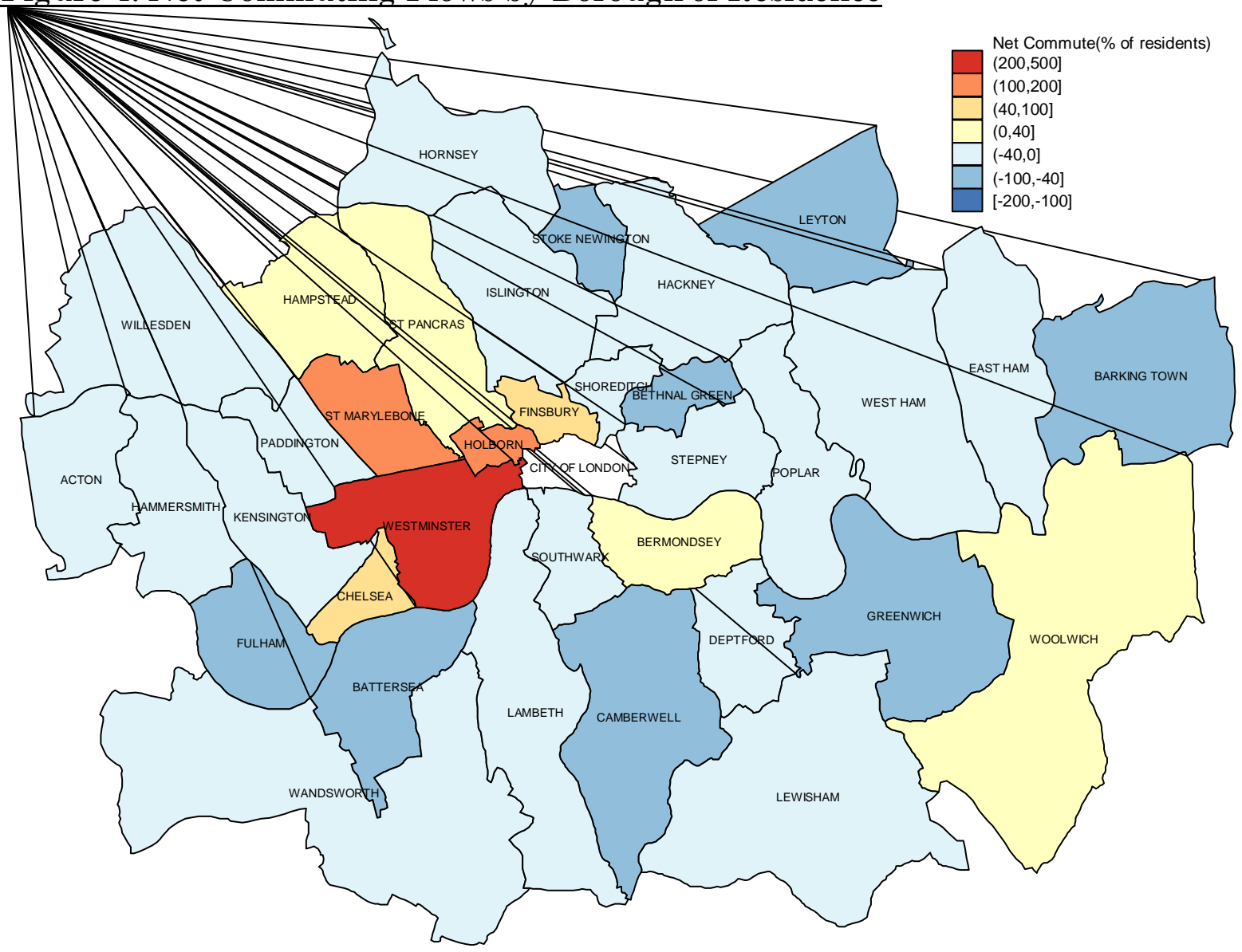

Notes: The map shows the net commuter flow by borough:

$\left(\frac{100 *(\text { individuals employed in borough } i-\text { employees residing in borough } i)}{\text { employees residing in borough } i}\right)$

The City of London is blank on the map as its residents were not included in the New Survey.

Sources: Johnson, et. al. (1999) and authors' calculations. 


\section{Appendix I: Information in the New Survey of London Life and Labour}

\section{Front of Card}

Name (Not recorded in Johnson, et. al (1999))

Address (street address)

Borough

For each wage earner

Relationship to head of household

Age

Occupation - see Johnson, et. al. (1999) for a description

Employer

Place of Work

Cost of transport weekly

Hours last week

Hours full time

Earnings last week (in s. and d.)

Earnings full time (in s. and d.)

State Insurance deductions (in s. and d.)

For each non-wage earner

Sex

Age

Relationship to head of household

Income from other sources

Source

Amount (in s. and d.)

Date of Interview

Interviewer

Back of Card

Birthplace of Adults

Rent, weekly (includes rates)

Persons and accommodation

No. of persons

No. of bedrooms

Parlour (yes or no)

Kitchen (number)

Scullery (yes or no)

Pantry or Larder (yes or no)

Bath (yes or no)

Yard (yes or no)

Garden (yes or no)

Allotment (yes or no)

Remarks on accommodation 
Table A.I.1

Summary Statistics

A. Individual Characteristics

\begin{tabular}{|l|c|c|}
\hline & All Individuals & Employed in the Previous Week \\
\hline Male (\%) & 48.7 & 70.5 \\
\hline Age & $\begin{array}{c}28.4 \\
(19.8)\end{array}$ & 32.6 \\
& 2.7 & $(14.4)$ \\
\hline Born outside England (\%) & 84.2 & 2.5 \\
\hline Born in London (\%) & 33.3 & 86.2 \\
\hline Living in borough of birth (\%) & 11.8 & 36.6 \\
\hline $\begin{array}{l}\text { Living in borough adjacent to } \\
\text { borough of birth (\%) }\end{array}$ & & 31.4 \\
\hline $\mathrm{N}$ & 93,891 & 35,282 \\
\hline
\end{tabular}

B. Household/Dwelling Characteristics

\begin{tabular}{|c|c|}
\hline Persons in the Household & $\begin{array}{c}3.5 \\
(1.9)\end{array}$ \\
\hline One-person household (\%) & 11.0 \\
\hline Two-person household (\%) & 24.6 \\
\hline Three-person household (\%) & 22.5 \\
\hline Four-person household (\%) & 17.2 \\
\hline Five + person household (\%) & 24.7 \\
\hline Non-wage income (d per week) & $\begin{array}{c}0.38 \\
(0.65)\end{array}$ \\
\hline Minimum distance to a central point $(\mathrm{km})$ & $\begin{array}{c}5.4 \\
(2.8)\end{array}$ \\
\hline Nearest central point $=$ Charing Cross $(\%)$ & 42.9 \\
\hline Rent (£ per week) & $\begin{array}{c}0.66 \\
(0.81)\end{array}$ \\
\hline Number of bedrooms & $\begin{array}{c}1.56 \\
(0.76)\end{array}$ \\
\hline Private [shared] parlour & $71.1 \quad[0.1]$ \\
\hline Private [shared] kitchen & $78.7 \quad[1.2]$ \\
\hline Private [shared] scullery & $50.3 \quad[9.0]$ \\
\hline Private [shared] pantry & $17.2[0.2]$ \\
\hline Private [shared] bath & $14.5[4.1]$ \\
\hline Private [shared] outdoor space & $70.6[14.4]$ \\
\hline Inner ring $(\%)$ & 30.1 \\
\hline Middle ring (\%) & 20.6 \\
\hline Exterior ring (\%) & 49.3 \\
\hline County of London (\%) & 81.8 \\
\hline $\mathrm{N}$ & 26,915 \\
\hline
\end{tabular}


Table A.I.1

Summary Statistics, Continued

C. Employment Characteristics

\begin{tabular}{|l|c|}
\hline Hours working in previous week & 46.1 \\
& $(8.3)$ \\
\hline \% age 16-65 reporting hours in previous week >0 & 54.9 \\
\hline Worked at least 40 hours (\%) & 90.8 \\
\hline Worked at least 48 hours (\%) & 57.1 \\
\hline Hours worked in a full-time week & 46.9 \\
& $(7.2)$ \\
\hline \% age 16-65 reporting hours in a full time week >0 & 56.1 \\
\hline Earnings in previous week (£) & 2.34 \\
& $(1.17)$ \\
\hline Earnings in a full-time week (£) & 2.38 \\
& $(1.17)$ \\
\hline Occupation = metal worker (\%) & 8.0 \\
\hline Occupation = electrical (\%) & 2.4 \\
\hline Occupation = makers of textile goods (\%) & 8.5 \\
\hline Occupation = food, drinks \& tobacco (\%) & 3.1 \\
\hline Occupation = wood \& furniture (\%) & 4.9 \\
\hline Occupation = printers \& photographers (\%) & 2.5 \\
\hline Occupation = building trades (\%) & 4.4 \\
\hline Occupation = painters \& decorators (\%) & 2.8 \\
\hline Occupation = transport and communications (\%) & 17.7 \\
\hline Occupation = Commerce, finance, insurance (\%) & 8.6 \\
\hline Occupation = personal service (\%) & 11.4 \\
\hline Occupation = clerk (\%) & 5.5 \\
\hline Occupation = warehousemen, storekeepers (\%) & 4.7 \\
\hline Occupation = other or unknown (\%) & 15.5 \\
\hline Armstrong skill category = professional (\%) & 0.1 \\
\hline Armstrong skill category = middling (\%) & 0.7 \\
\hline Armstrong skill category = skilled (\%) & 49.0 \\
\hline Armstrong skill category = semi-skilled (\%) & 24.0 \\
\hline Armstrong skill category = unskilled (\%) & 26.1 \\
\hline N & 35,353 \\
\hline
\end{tabular}

Notes: Standard errors are reported in parentheses for continuous variables. Age is reported as zero in 9.2 percent of observations. We have excluded these observations from our calculations in Table A.I. 1 and included a dummy variable for the regressions reported in Tables 4 and 5 . Outside space comprises garden, yard, and allotment. Some households had multiple types of outdoor space and some had both private and shared space.

Sources: Johnson, et. al. (1999) and authors' calculations. 


\section{Appendix II: Coding GIS Coordinates and Distances}

This appendix outlines our approach to GIS coding of home street addresses, workplace locations, and the public transport network. We also outline how we use these GIS coordinates to construct our measures of distance commuted, access to public transport, and centrality. Finally, we examine measurement error and biases that are likely to result from our approach and the likely implications for our results.

\section{Residential Addresses}

Our approach to GIS coding home addresses is as follows. First, we have entered the street name into streetmap.co.uk. If there exists exactly one modern street with the same name that is located within the historic Metropolitan Borough listed on the original record we assume this to be the residential address. We then take the GIS coordinates from streetmap.co.uk. Occasionally there are multiple streets of the same name within the same historic borough, e.g. two towns have a "High St.". Normally in these cases, the records themselves indicate the correct street. For example, the streets may be listed as "High St., Woolwich" or "High St., Plumstead". In cases such as this, the street is clearly identified even though the official name of both streets is just "High St." and both Woolwich and Plumstead were in the Metropolitan Borough of Woolwich. In the small handful of cases where there remained ambiguity, we have looked at additional information from the record cards to determine the most likely correct address (e.g. whether household members were working in Plumstead or Woolwich).

For about a quarter of the observations, we were unable to find the address listed on the record card in streetmap.co.uk due to changes of street names. London was extensively bombed during the Second World War. Many homes and even entire neighbourhoods were damaged beyond repair (Ward 2015). After the War, London's urban planners "cleared" many War-damaged areas and other urban slums. The clearances disproportionately affected working-class areas, as wealthier areas which suffered minor bomb damage were quickly rebuilt. The clearances often changed the physical layout of the area, for example replacing low-rise dwellings with high-rise council housing (Sturm and Redding 2016).

To locate no-longer-extent streets, we began by searching the online indexed maps from the LLPL (London School of Economics 2020). Because of the similarity of coverage between the two surveys, most residential streets within the County of London appearing in the NSLLL previously appeared in the LLPL. We were thus normally able to find residential streets on the LLPL map and obtain GIS coordinates from Ordinance Survey maps (National Library of Scotland 2020). In cases where a street was not included in the LLPL index (particularly in the outer boroughs not surveyed in the LLPL), we have searched other on-line resources such as Medical Officer of Health Reports, Census Street Index, and various genealogical web sites (Welcome Library 2021; Family Search 2021). Often, we were able to find an exact or at least an approximate location for a residential street, usually based on known locations for nearby streets that were listed in the 
same source. Once we found the location, we then found the GIS coordinates using Ordinance Survey maps (National Library of Scotland 2020). ${ }^{40}$

When entering GIS coordinates, we have used a single centroid for each home address in the data. ${ }^{41}$ The centroid will either be the location used by Streetmap.co.uk (for still-extent streets) or at approximately the middle of the street (for no-longer-extent streets). The approach of using a single centroid facilitates checking for inconsistencies in the data. It also makes it possible to replicate our GIS coding procedure, as it avoids non-replicable $a d$ hoc assumptions about individual locations.

We believe that home addresses were very accurately recorded by the NSLLL enumerators. The enumerators were instructed to visit each individual household; hence they actually set foot on the residential street. We have been able to locate well over 99 percent of home addresses in the data. Although our use of a single centroid for each address will inevitably create some measurement error, we believe that this measurement error is likely to be small because working-class residential streets tended to be fairly short.

\section{Workplace addresses}

Our approach to obtaining GIS coordinates for workplaces closely follows that of home addresses. We searched streetmap.co.uk, followed by the indexed LLPL maps, followed by other on-line sources to identify workplace streets or place names. If this failed to produce a likely match, we searched old Ordinance Survey maps (National Library of Scotland 2020) for similarly named streets nearby the place of residence. ${ }^{42}$

There are several sources of measurement error for workplaces that are not present for residences. First, the survey question for workplace is less precise than residence, asking for "place of work" rather than "address". Accordingly, the responses were more varied than for home addresses, ranging from an exact address, to just a street name, to a broader place name. About half the responses are place names. Even place names can be imprecise. For example, "Greenwich" is the name of both a Metropolitan Borough and the main town within the borough. Where a place name is reported, we enter a common GIS coordinate using the centroid of the smallest plausible geographic unit (e.g. town, rather than borough). If the record card provides a general, but very broad area (e.g. "London" or "East

\footnotetext{
40 National Library of Scotland (2020) contains a variety of scalable modern and historic street maps which can be uploaded side-by-side. Our GIS coding has primarily relied on OpenStreetMap; Ordinance Survey (OS), 25 inches, 1892-1914; and OS 1/2500, 1944-1967.

41 We have used the street/borough pair when assigning centroids. Most streets were entirely contained within a single borough and we assign a single set of GIS coordinates to these streets. In cases were a street passed through multiple boroughs, we assign a single centroid for each borough covered by the street. Street names tended to change at borough boundaries, so there are very few residential streets with multiple coordinates in the data.

${ }^{42}$ Since enumerators relied on residents to provide workplace addresses, there were fairly frequent transcription errors or spelling mistakes on the original records. We were often able to find very similar (or identically pronounced) workplace street names by searching the map around the home address.
} 
End"), we treated for place of work as missing unless we could identify a more specific location based on the employer. The lack of precision in workplace locations implies that our GIS coordinates are inherently subject to more measurement error than for home addresses. In addition, commercial streets tended to be longer than residential streets and thus there is likely to be more measurement error for workplaces than residences, even in cases where a street is listed for both. A final issue is that in about eight percent of observations with pay reported the place of work is listed as "various" or "casual". We assume these workers to either be footloose (such as in the building trades) or itinerant. We do not assign workplace locations to these workers.

A second difficulty identifying workplaces is that, unlike the home addresses, the original record cards do not contain boroughs for workplace. ${ }^{43}$ This makes it more difficult to identify the workplace location for common London street names, unless the location is given on the original record card, e.g. "High St., Plumstea d". In cases where a workplace address was ambiguous, we used other data from the record such as home address, name of employer, and travel costs to identify the most plausible location. ${ }^{4}$

A final issue results from the fact that enumerators never visited places of work, instead they relied on information supplied by interviewees. At best, this meant that the address was from second-hand information from the worker, rather than directly from the enumerator. However, it is likely that the information was often supplied by another member of the household. Although the New Survey enumerators were explicitly instructed to make repeated visits to households in order to get employment information from the income earner themselves, it is known that Arthur Bowley, the overseer of the NSLLL, was willing to "sacrifice accuracy to speed and simplicity" (Abernathy 2017; Hennock 1991).45 Responses from someone other than individual workers themselves were probably widely tolerated. ${ }^{46}$

\footnotetext{
${ }^{43}$ The Johnson, et. al (1999) data contains a variable for workplace borough. However, this has been constructed by the researchers and is not from the original record cards. We have created a new variable for workplace borough by mapping the NSLLL area into approximately 500 square meter grids. We map each observation into a cell using the GIS coordinates. We then map the grid cells into boroughs. In cases where a grid cell is divided between more than one borough, we mapped workplace addresses within the cell into boroughs by hand using Ordinance Survey maps (OS 25 inches, 1892-1914).

${ }^{44}$ Locations of larger employers often turned up in on-line searches, and we were often able to identify precise GIS coordinates using this information.

45 It was noted in the original instructions to enumerators that "Vague estimates of husband's earnings by wife, of child's by parent, or of lodger's by landlady, should not be entered until an effort has been made to see the wage earner concerned" (New Survey, instructions issued to investigators, quoted in Abernathy 2017).

${ }^{46}$ Missing or imprecise workplace information is much more common in the NSLLL data for lodgers than family members. It is difficult to reconcile this with earners supplying their own information, but consistent with a single (non-working) resident supplying information for all household members. In addition, the original record cards often provide relatio nships within households visà-vis someone other than the likely head of household. Johnson, et. al (1999) have reclassified household relationships using the age, gender, and earnings data to identify the head. The fact that the head of household was frequently not correctly identified by the enumerators is strongly
} 
Although the issues raised above imply that workplace addresses are more prone to measurement error than home addresses, we believe that they are nevertheless fairly accurate. We were able to obtain GIS coordinates for about 98 percent of observations where a street or place name is given for place of work. When we were unable to obtain workplace GIS coordinates, it was typically because either the worker was itinerant or the original respondent did not supply the necessary information. In about 12 percent of observations reporting earnings in the previous week the information is either missing or unusable ("X", "refused", "London", etc.).

\section{Public transport}

We have compiled a list of railway and London Underground stations in 1929 using historic Underground maps (Graham-Smith 2018), historic Ordinance Survey maps (National Library of Scotland 2020), and Wikipedia lists of current and historic stations (Wikipedia 2020a, 2020b, 2020c, 2020d). Wikipedia usually provides GIS coordinates for rail and Underground stations and we cross-checked these using historical Ordinance Survey maps (National Library of Scotland 2020). We thus believe that these GIS coordinates are very accurate.

We obtained detailed information on bus and tram routes from London Historical Research Group (2014) and Public (2020), respectively. However, neither source indicates where vehicles stopped along the route. We have used OpenStreetMap to find the location of modern bus stops and assumed that these correspond to stops on the historic routes. Where the historic routes do not coincide with modern routes, we have assumed that stops were 300-500 meters apart in central areas and slightly further apart in outer areas, as with modern routes. We start with a known stop on route, such as the route terminus or a railway station, and assign stops approximately equidistant from this point. In addition to official stops, it was generally possible for able-bodied passengers to board or leave a bus or tram at any point where the vehicle was stopped and thus we also classify major intersections as stops. ${ }^{47}$ There will be some measurement error in this approach that is absent in our calculations for rail and Underground (for which we know the exact location for each station), but this is likely to be fairly small, as tram and bus stops were generally fairly close together.

\section{Calculating Distances}

We have used the GIS coordinates to calculate crow-flies distances between home, work, the city centres, and public transport for each employed individual in the sample. Conceptually, these distances are 1) the distance commuted (home to work), 2) the centrality of their home or workplace (minimum distance to Charing Cross or the Bank of England), and 3) access to public transport (distance to bus, tram, Underground, or train). Figure A.II.1 shows these distances for one individual. On the map, the residence is denoted $\mathrm{H}$, the workplace is denoted $\mathrm{W}$, the nearest Underground stop to home is denoted U, and Charing Cross is denoted

suggestive that they made a single visit to the household and collected all information from the person who answered the door.

47 The buses and trams of the 1930s were "routemaster" design with an open entrance at the back. Passengers could embark or disembark at any point on route when the bus was stopped. 
CX. The black line shows the crow-flies distance between home and work (commuting distance). The green line shows the distance between home and Charing Cross (centrality). The solid red line between $\mathrm{H}$ and $\mathrm{U}$ shows the distance from home to the nearest underground station. The dotted and solid red lines connected to this show the most plausible transport route to work (by underground for two stops and a short walk to the workplace at the end). For ease of exposition, we have not shown the other distances on this map.

To calculate distances, we use the great circle distance formula:

$$
d=R^{*} a \cos \left(\sin \left(l a t \_a\right)^{*} \sin \left(l a t \_b\right)+\cos \left(l a t \_a\right)^{*} \cos \left(l a t \_b\right)^{*} \cos \left(d \_l o n\right)\right) \text {; }
$$

where: $\quad \mathrm{R}=$ radius of the earth (6365 kilometres)

lat_a, lat_b = latitudes of points a and b

d_lon = difference in longitude between the two points.

There were a few exceptions to these principles in our calculations of distance. As mentioned above, if a worker was deemed to be itinerant, we did not fix workplace coordinates, and thus could not calculate distances. In addition, if the original record card listed workplace as some variant of "local" or "nearby", we assume a commuting distance of 0.5 kilometres and that workplace centrality is the same as home centrality. These cases account for approximately 2.4 percent of observations.

There are also observations for which the distances between home and workplace were very large. It is likely that these workers were stationed remotely and did not commute on a daily basis. Thus, in our main analysis, we exclude the 76 observations where the distance between home and work was over 50 kilometres. We have also set the cut-off at 20 kilometres (which excludes an additional 117 observations) and included long commutes in the analysis as robustness checks. Our results are not particularly sensitive to the rule used for exclusion of outliers.

\section{Measurement error and bias}

For the most part, errors in our distance variables will simply be classical measurement error, resulting from our inability to identify precise locations for home, workplace, bus stops, and tram stops. As noted above, the extent of this measurement error is likely to be larger for workplaces than for residences or public transport. The consequence of this measurement error will be attenuation bias in our estimates of the effects of distances on earnings. In other words, our estimated returns to commuting in Section VII are likely to be biased downwards.

In addition to this measurement error, there exist two likely sources of systematic bias in our variable for distance commuted. First, we are less likely to find workplace locations for individuals who had longer commutes. When we could not find a workplace through other means, our final approach was to search the map in proximity to the worker's residence. This approach helped locate numerous workplaces, but it also implies that we are more likely to be missing data for 
workplace location if a worker's residence was further from home, and thus had a longer commute. This will bias the estimated travel distances in Section VI downwards. It will also bias the estimated effects of commuting on earnings upwards. However, we do not feel that these biases are likely to be large because we have been able to locate all but about two percent of workplaces named on the original record cards.

A more serious concern results from our use of a single centroid for each residential street and workplace location. As noted above, the use of a single centroid is likely to result only in measurement error for residential addresses or workplace locations, taken individually. However, the location of an individual's workplace is not independent of their residence. For example, a worker who resides on a short north-south street that intersects a lengthy east-west workplace street near its eastern end is more likely to work around the corner at the eastern end of the workplace street than a couple kilometres away at the centroid of the street. Similarly, a worker whose workplace is reported as a borough adjacent to their borough of residence is more likely to be employed near the border of the two boroughs than at the centroid of the workplace borough. Consequently, we are likely to systematically overestimate the distance commuted, and thus underestimate the returns to commuting.

The net bias resulting from our approach is almost certainly to underestimate the returns to distance commuted. On the other hand, there is likely to be little bias in our estimated returns to access to public transport, as these distances are measured with little error. As a result, we think our results in Section VII represent a lower bound on the returns to distance commuted but are fairly accurate on the returns to access to public transport.

\section{References}

Abernethy, Simon T. (2017). "Deceptive data? The role of the investigators in the New Survey of London Life and Labour 1928-32." Historical Methods A Journal of Quantitative and Interdisciplinary History, 50(1):1-15.

Family Search (2021). Census Street Index. https://www.familysearch.org/wiki/en/Census_Street_Indexes [Accessed 25/9/2020].

Graham-Smith, Darien (2018). "The history of the tube map". Londonist. https://londonist.com/2016/05/the-history-of-the-tube-map [Accessed 25/9/2020].

Hennock, E. P. (1991). "Concepts of poverty in the British social surveys from Charles Booth to Arthur Bowley.” In M. Bulmer, K. Bales, and K. K. Sklar, eds. The Social Survey in Historical Perspective. (Cambridge: Cambridge University Press), pp. 189-217.

Johnson, Paul A., Bailey, Roy E., Baines, Dudley E., Raspin, Anna, Hatton, Timothy J. (1999). New Survey of London Life and Labour, 1929-1931. [data collection]. 2nd Edition. UK Data Service. SN: 3758, http://doi.org/10.5255/UKDA-SN-3758-1. 
https://beta.ukdataservice.ac.uk/datacatalogue/studies/study?id=3758

[Accessed 25/9/2020].

London Historical Research Group, The Omnibus Society (2014): Motor Omnibus Routes in London, vol. 10A (1 ${ }^{\text {st }}$ January 1931 to $31^{\text {st }}$ December 1932) (Sevenoaks: London Historical Research Group).

London School of Economics (2020). Charles Booth's London: Poverty Maps and Police Notebooks. https://booth.lse.ac.uk/map/14/-0.1174/51.5064/100/0 [accessed 13/9/2020].

National Library of Scotland (2020). Side-by-Side Map Images. https://maps.nls.uk/ [Accessed 25/9/2020].

Public (2020). "Trams in London." http://sharemap.org/public/Trams_in_London\#!webgl [Accessed 25/9/2020].

Redding, Stephen and Sturm, Daniel (2016). "Estimating neighbourhood effects: evidence from War-time destruction in London." Mimeo, London School of Economics.

Streetmap (2020). https://www.streetmap.co.uk/ [accessed 25/9/2020].

Ward, Laurence (2018). The London County Council Bomb Damage Maps, 19391945. (London: Thames \& Hudson).

Welcome Library (2021). The Medical Officer of Health Reports. https://wellcomelibrary.org/moh/about-the-reports/about-the-medicalofficer-of-health-reports/ [accessed 25/9/2020].

Wikipedia (2020a). "List of London railway stations." https://en.wikipedia.org/wiki/List_of_London_railway_stations [accessed 25/9/2020].

Wikipedia (2020b). "List of closed railway stations in London." https://en.wikipedia.org/wiki/List_of_closed_railway_stations_in_London [accessed 25/9/2020].

Wikipedia (2020c). "List of London Underground stations." https://en.wikipedia.org/wiki/List_of_London_Underground_stations [accessed 25/9/2020].

Wikipedia (2020d). "List of former and unopened London Underground stations." https://en.wikipedia.org/wiki/List_of_former_and_unopened_London_Under ground_stations [accessed 25/9/2020]. 
Figure A.II.1

Distances for One Individual

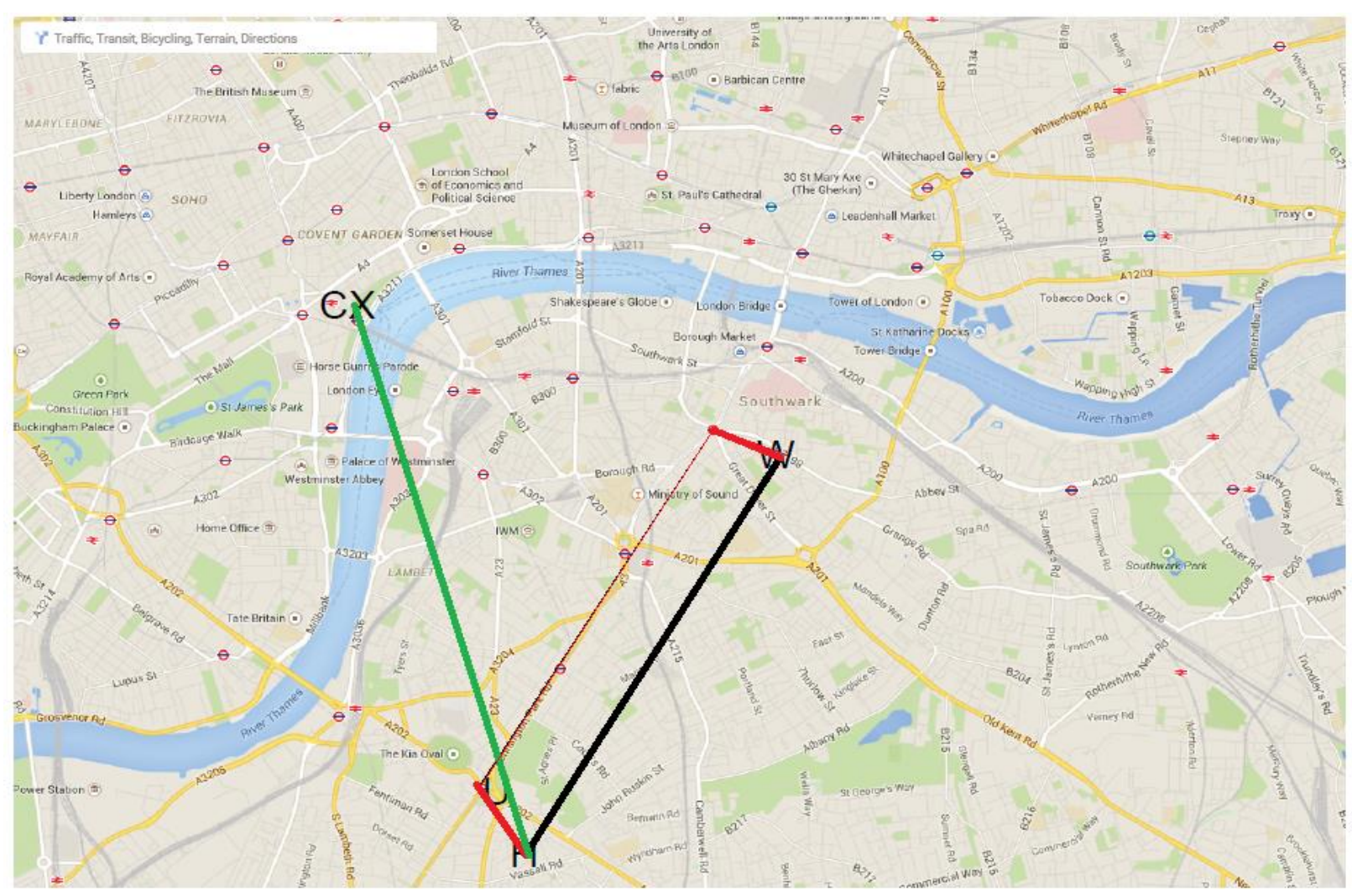




\section{Appendix III: Costs and Benefits of Commuting and Calculating Poverty Lines}

\section{I. $\quad$ Costs and benefits of Commuting}

Table 6 shows the costs and benefits of commuting. The calculations in this table are very much back-of-the-envelope, but are informed by stylized facts from Ponsonby and Ruck (1930) and from the New Survey data. In this appendix we describe the assumptions behind these calculations and examine their historical basis.

Crow-flies distances:

The distances in the first column are arbitrary round numbers, which cover the range of distances commuted. The range of distances covers virtually all workers who were not working "on the spot" (the term used by Ponsonby and Ruck (1930) to describe the proximity of employment to residence in the 1890s). Approximately 86 percent of income earners in the sample travelled at least 500 meters; approximately 99 percent travelled at most 16 kilometres.

Transport mode:

Ponsonby and Ruck (1930) state that workers typically walked up to 1.6 kilometres, buses and trams were used interchangeably for distances of 1.6 to 3.2 kilometres, the Underground was typically used for distances of 3.2 to 19.3 kilometres, and trains were used for longer distances or as a replacement for the Underground in places where it was not available. Approximately 82.9 percent of workers with non-missing transport costs who travelled distances of up to 1.6 kilometres, reported costs of exactly zero, and thus must have walked or cycled. Approximately, 83.7 percent of individuals with non-missing transport costs who commuted over 1.61 kilometres, reported positive costs, and thus must have used public transport. We do not observe the mode of transport, but the relationship between proximity to stops/stations and commuting distances shown in the regressions in Table 4 is consistent with the pattern reported by Ponsonby and Ruck (1930).

\section{Distance walked:}

We construct as the crow-flies, distances i.e. in a straight line. The urban layout rarely allows this to be the actual route, thus actual distance travelled must be greater than crow-flies distance. There exists a substantial literature in geography on the difference between crow-flies and actual distances (Rietveld, et. al. 1999 and Underhill 2020). We assume, somewhat arbitrarily, that walking-only journeys were 25 percent longer than the crow-flies distance. Any journey involving public transport would have also involved walking from home to transport and from transport to work. Table 3 shows the average distance from home and work to each public transport mode. However, workers would have chosen their mode of transport at least partly based on proximity, so the walking 
distance to the chosen mode of transport will have on average been less than for modes not used. We assume 300 meters of total walking at both ends for a oneway bus journey, about 75 percent of the sum of average distances from the nearest bus stop to home and workplace. We also assume 300 meters of walking for a oneway tram journey. This is considerably less than the average distance shown in Table 3; however, one would expect that the distance walked by tram users would have been approximately the same as bus users, as the two modes of transport were used interchangeably. We assume 600 meters of walking at both ends for a one-way Underground or train journey, about 75 percent of the maximum distance that geographers have argued that commuters are willing to walk to these modes of transport (Daniels and Mulley 2013).

Distance on public transport:

As with walking, public transport generally does not travel in a straight line and this adds to the total distance. On the other hand, in many cases workers can choose between stops which are approximately equidistant to home (work). If there are two approximately equidistant stops from home, a worker would have been more likely to use the one closer to their work in order to minimize total travel time. This will at least partly offset the effect of added distance due to non-linear transport routes, and thus we assume that the travel distance for public transport is only 10 percent more than the crow-flies distance of total travel.

With each of our assumptions about distance, there is likely to be considerable heterogeneity across individuals and locations. The assumptions are not verifiable in the data, so it is also possible that there is some error on average. However, it is unlikely that modest errors in either direction will have a substantial impact on our conclusions in Section VI.

Walking and public transport time:

Time is calculated as distance (from columns 3 and 4 in Table 6) divided by speed. Following Leunig (2006), we use 4 kilometres per hour as a typical urban walking speed. We take public transport speeds from Table 2. Neither Ponsonby and Ruck (1930) nor London Statistics provide train speeds after the first World War and we assume that average speeds in 1930 were 10 percent faster than those reported in London Statistics for 1907-08.

Implied return:

We use the first regression in Table 5, evaluated at the tenth, twenty fifth, and fiftieth percentiles of the weekly earnings distribution $(180 \mathrm{~d}, 300 \mathrm{~d}$, and $583.5 \mathrm{~d})$ to calculate the returns to commuting the distances shown in the first column. Specifically, we estimate the returns as:

$$
\operatorname{Exp}\left[\ln (W E)+.02577 d-.00489 d^{2}\right]-\operatorname{Exp}[\ln (W E)]
$$

where: 
$\mathrm{WE}=$ weekly earnings (in pence), evaluated at the $10^{\text {th }}, 25^{\text {th }}$, and $50^{\text {th }}$ percentile $\mathrm{d}=$ distance commuted, in kilometres (from Table 6, column 1 )

\section{Monetary costs:}

We use reported transport expenses from the New Survey data and the description of travel costs from Ponsonby and Ruck (1930) to determine a "typical" cost for the journey in each row. Public transport fares were set by zones, which were imperfectly correlated to distance. For any given distance and mode of transport there may have been multiple fares, depending on the embarkation and disembarkation stations. The monetary costs reported in Table 6 are the range of typical fares reported in the New Survey data for workers commuting distances within 500 meters of the crow-flies distances in column 1.48

Implied time costs:

The total time spent commuting is the sum of walking time, transport time, and waiting time. We assume five minutes waiting time for the bus and tram and eight minutes for the train and Underground. We assume a longer time for train and Underground because the platform was physically removed from the entrance to the station. Following an extensive literature on the value of travel time saved, we use 50 percent of salary as the implied cost of commuting time (Wardman 1998; Zamparini and Reggiani 2007). In the second column of Table 6, we assume a single mode of transport. In practice, some commuters, particularly those with longer commutes, may have needed to transfer between modes and thus incurred additional waiting time.

\section{The Hatton-Bailey Poverty Line}

The appendix in Hatton and Bailey (1998) outlines their approach to constructing household poverty lines. To briefly summarize, they allocate minimum required expenditures on food and clothing, rent, and fuel. The minimum required expenditure on food and clothing is based on age and sex of the individual and ranges from $36 \mathrm{~d}$ per week for a child under age 1 to $102 \mathrm{~d}$ per week for males aged 18 and over. The minimum required rental expenditure is based on a standard of no more than two individuals to a room and a cost of $60 \mathrm{~d}$ per week for one room, $102 \mathrm{~d}$ per week for two rooms, $126 \mathrm{~d}$ per week for three rooms, and $30 \mathrm{~d}$ per week for each additional room. The minimum required expenditure on fuel is $36 \mathrm{~d}$ per week, plus an additional $2 \mathrm{~d}$ in South London. A household is classified as poor if the sum of these minimum expenditures and actual household expenditures on transport and National Insurance is greater than their total income from all sources. The New Survey reports income in previous week and in a full-time week and Hatton and Bailey (1998) use income from the previous week for the poverty calculations. The estimated poverty lines using this approach are 198, 292, 392, 588 pence per week for a household with only a single adult male, a married couple, a couple with one child, and a couple with three children, respectively. Hatton and Bailey

48 The New Survey data typically reports weekly expenditures on transport. We divide this by 12 to find one-way fares. In each case, the range reported in Table 6 covers both the median and modal fare. 
(1998) estimate that 12.11 percent of households and 12.0 percent of individuals fell below the poverty line.

We have made two adjustments to their calculations. First, approximately 9.2 percent of individuals in the New Survey have a reported age of exactly zero. This is an implausibly large number and almost certainly indicates that age was not reported in most of these observations. We have reclassified these individuals as adults and adjusted required expenditure on food and clothing if 1) they had an occupation or reported earnings or hours worked or 2) their relationship to the head of household indicates they must have been an adult (e.g. wife or grandfather). If the individual was not an income earner and was plausibly a child (e.g. son or nephew of the head), we use a value of zero for age and assign minimum expenditure accordingly. The reclassification of children age zero to adults (age $18+)$ increases the minimum expenditure on food and clothing from 38d per week to $102 \mathrm{~d}$ per week for 3742 men and to $94 \mathrm{~d}$ per week for 4792 women. It is likely that many of those we still classify as age zero were actually older and thus would require greater expenditures than for an infant, so our upwards adjustment to the poverty line is a lower-bound. Secondly, both National Insurance contributions and transport expenses are frequently missing in the New Survey data. Among individuals reporting earnings or hours in the previous week, approximately 30 percent are missing data for transport costs and approximately 20 percent are missing data for National Insurance contributions. We have handled missing data in two ways: constructing a lower-bound poverty line where missing observations are replaced by a value of zero and an expected value poverty line where missing observations are replaced by the overall sample mean. These reclassifications increase the poverty line for 4730 households and increase the number of individuals classified as poor from 12.0 percent of the sample (Hatton and Bailey 1998, p. 584) to 16.7 percent of the sample (lower-bound poverty line) or 20.6 percent of the sample (expected value poverty line).

\section{References}

Daniels, Rhonda and Mulley, Corinne (2013). "Explaining walking distance to public transport: The dominance of public transport supply." Journal of Transport and Land Use,

6(2): 5-20.

Leunig, Tim (2006). "Time is money: a re-assessment of the passenger social savings from Victorian British railways." Journal of Economic History, 66(3): 635-73.

London County Council (various years). London Statistics. (London: P. S. King and Son).

Ponsonby, G. and Ruck, S. K. (1930). "Travel and mobility". In Llewellyn-Smith, Hubert, eds. The New Survey of London Life and Labour. (London: P. S. King), pp. 171-99.

Rietveld, Piet, Zwart, Bert, van Wee, Bert, van den Hoorn, Toon (1999). "On the relationship between travel time and travel distance of commuters." Annals of Regional Science, 33(3): 269-87. 
Underhill, Keziah (2020). "December visualisation blog: crow flies vs. OD paths." https://www.basemap.co.uk/december-visualisation-blog-crow-flies-vs-odpaths/ [accessed 23/02/2021].

Wardman, Mark (1998). "The value of travel time: A review of British evidence." Journal of Transport Economics and Policy, 32(3): 285-316.

Zamparini, Luca and Reggiani, Aura (2007). "Meta-analysis and the value of travel time savings: a transatlantic perspective in passenger transport." Networks and Spatial Economics, 7(4): 377-96. 


\section{Appendix IV: Additional Tables and Figures}

Table A.IV.1: Estimated Effects of Control Variables on Labour Force $\underline{\text { Participation }}$

\begin{tabular}{|c|c|c|c|c|c|c|c|}
\hline & (1) & $(2)$ & (3) & (4) & $(5)$ & (6) & (7) \\
\hline & Hours $>0$ & In Work & Distance & $\begin{array}{c}\text { Distance } \\
\text { (Heckman) }\end{array}$ & $\begin{array}{c}\text { Transport } \\
\text { Costs }=0\end{array}$ & $\begin{array}{l}\text { Distance } \\
<1 \mathrm{Km}\end{array}$ & $\begin{array}{l}\text { Distance } \\
>3.2 \mathrm{Km}\end{array}$ \\
\hline Age & $\begin{array}{l}-1.558^{*} \\
(0.056)\end{array}$ & $\begin{array}{l}-1.630^{*} \\
(0.053) \\
\end{array}$ & $\begin{array}{l}10.195^{*} \\
(1.478)\end{array}$ & $\begin{array}{l}6.873^{*} \\
(1.771) \\
\end{array}$ & $\begin{array}{l}-1.130^{*} \\
(0.001) \\
\end{array}$ & $\begin{array}{l}-0.633^{*} \\
(0.122) \\
\end{array}$ & $\begin{array}{l}1.104^{*} \\
(0.127)\end{array}$ \\
\hline Age squared & $\begin{array}{l}0.009^{*} \\
(0.001)\end{array}$ & $\begin{array}{l}0.009^{*} \\
(0.001)\end{array}$ & $\begin{array}{l}-0.144^{*} \\
(0.020)\end{array}$ & $\begin{array}{l}-0.129^{*} \\
(0.020)\end{array}$ & $\begin{array}{l}0.170^{*} \\
(0.020)\end{array}$ & $\begin{array}{l}0.011^{*} \\
(0.002)\end{array}$ & $\begin{array}{l}-0.016^{*} \\
(0.002)\end{array}$ \\
\hline $\begin{array}{l}\text { Age reported as } \\
\text { zero }\end{array}$ & $\begin{array}{l}-0.599^{*} \\
(0.012)\end{array}$ & $\begin{array}{l}-0.570^{*} \\
(0.011)\end{array}$ & $\begin{array}{l}1.825^{*} \\
(0.276)\end{array}$ & $\begin{array}{c}0.518 \\
(0.484) \\
\end{array}$ & $\begin{array}{l}-0.131^{*} \\
(0.028) \\
\end{array}$ & $\begin{array}{l}-0.064^{*} \\
(0.024) \\
\end{array}$ & $\begin{array}{l}0.186^{*} \\
(0.024) \\
\end{array}$ \\
\hline Female & $\begin{array}{l}-0.341^{*} \\
(0.003)\end{array}$ & $\begin{array}{l}-0.380^{*} \\
(0.003)\end{array}$ & $\begin{array}{l}-0.418^{*} \\
(0.062)\end{array}$ & $\begin{array}{l}-1.041^{*} \\
(0.200)\end{array}$ & $\begin{array}{l}-0.015^{*} \\
(0.007)\end{array}$ & $\begin{array}{l}0.027^{*} \\
(0.006)\end{array}$ & $\begin{array}{l}-0.046^{*} \\
(0.006)\end{array}$ \\
\hline Born in England & $\begin{array}{l}0.077^{*} \\
(0.007)\end{array}$ & $\begin{array}{l}0.070^{*} \\
(0.007)\end{array}$ & $\begin{array}{l}-0.176 \\
(0.185)\end{array}$ & $\begin{array}{l}-0.004 \\
(0.152)\end{array}$ & $\begin{array}{c}0.019 \\
(0.014)\end{array}$ & $\begin{array}{l}-0.001 \\
(0.012)\end{array}$ & $\begin{array}{l}-0.022 \\
(0.012)\end{array}$ \\
\hline Born in London & $\begin{array}{l}0.188^{*} \\
(0.006)\end{array}$ & $\begin{array}{l}0.192^{*} \\
(0.006)\end{array}$ & $\begin{array}{l}-0.214 \\
(0.139)\end{array}$ & $\begin{array}{c}0.163 \\
(0.159)\end{array}$ & $\begin{array}{l}-0.009 \\
(0.011)\end{array}$ & $\begin{array}{c}0.001 \\
(0.009)\end{array}$ & $\begin{array}{l}-0.014 \\
(0.009)\end{array}$ \\
\hline $\begin{array}{l}\text { Born and lives in } \\
\text { the same borough }\end{array}$ & $\begin{array}{l}-0.029^{*} \\
(0.005)\end{array}$ & $\begin{array}{l}-0.037^{*} \\
(0.004)\end{array}$ & $\begin{array}{l}-0.165^{*} \\
(0.081)\end{array}$ & $\begin{array}{l}-0.187^{*} \\
(0.090)\end{array}$ & $\begin{array}{l}0.031^{*} \\
(0.009)\end{array}$ & $\begin{array}{c}0.010 \\
(0.007)\end{array}$ & $\begin{array}{l}-0.023^{*} \\
(0.008)\end{array}$ \\
\hline $\begin{array}{l}\text { Borough is } \\
\text { adjacent to birth } \\
\text { borough }\end{array}$ & $\begin{array}{l}-0.055^{*} \\
(0.006)\end{array}$ & $\begin{array}{l}-0.071^{*} \\
(0.006)\end{array}$ & $\begin{array}{l}-0.209^{*} \\
(0.102)\end{array}$ & $\begin{array}{l}-0.280^{*} \\
(0.138)\end{array}$ & $\begin{array}{l}-0.004 \\
(0.013)\end{array}$ & $\begin{array}{l}-0.019 \\
(0.011)\end{array}$ & $\begin{array}{c}0.009 \\
(0.012)\end{array}$ \\
\hline Other family pay & $\begin{array}{l}-0.000^{*} \\
(0.000)\end{array}$ & $\begin{array}{l}-0.001^{*} \\
(0.000)\end{array}$ & & & & & \\
\hline $\begin{array}{l}\text { Non-labour income } \\
\text { household }\end{array}$ & $\begin{array}{l}-0.002^{*} \\
(0.000)\end{array}$ & $\begin{array}{l}-0.002^{*} \\
(0.000)\end{array}$ & & & & & \\
\hline Observations & 51,970 & 51,970 & 23,254 & 51,970 & 19,147 & 23,254 & 23,254 \\
\hline
\end{tabular}

Notes: Coefficients on Age and Age squared are multiplied by 100. See Table 4 for additional results and notes.

Sources: Johnson, et. al. (1999) and authors' calculations. 
Table A.IV.2: Distance Effects on Labour Force Participation: All Family Members in a Household

\begin{tabular}{|l|c|c|c|c|c|c|c|}
\hline & $(1)$ & $(2)$ & $(3)$ & $(4)$ & $(5)$ & $(6)$ & $(7)$ \\
\hline & $\begin{array}{c}\text { Hours>0: } \\
\text { Probit }\end{array}$ & $\begin{array}{c}\text { In } \\
\text { Work: } \\
\text { Probit }\end{array}$ & $\begin{array}{c}\text { Dist. to } \\
\text { Work: } \\
\text { OLS }\end{array}$ & $\begin{array}{c}\text { Dist. to } \\
\text { Work: } \\
\text { Heckman }\end{array}$ & $\begin{array}{c}\text { Trans. } \\
\text { Costs=0: } \\
\text { Probit }\end{array}$ & $\begin{array}{c}\text { Dist. to } \\
\text { Work<1Km: } \\
\text { Probit }\end{array}$ & $\begin{array}{c}\text { Dist. to } \\
\text { Work>3.2Km: } \\
\text { Probit }\end{array}$ \\
\hline Distance-Centre & -0.001 & $-0.005^{*}$ & $0.441^{*}$ & $0.410^{*}$ & $-0.052^{*}$ & $-0.057^{*}$ & $0.060^{*}$ \\
$(0.002)$ & $(0.002)$ & $(0.035)$ & $(0.038)$ & $(0.003)$ & $(0.003)$ & $(0.003)$ \\
\hline Distance Home-Train & $0.024^{*}$ & 0.007 & -0.100 & -0.072 & 0.011 & -0.010 & -0.008 \\
& $(0.005)$ & $(0.005)$ & $(0.105)$ & $(0.109)$ & $(0.009)$ & $(0.008)$ & $(0.008)$ \\
\hline Distance Home- & 0.005 & -0.003 & $-0.182^{*}$ & $-0.179^{*}$ & $0.039^{*}$ & $0.041^{*}$ & $-0.026^{*}$ \\
Underground & $(0.003)$ & $(0.003)$ & $(0.080)$ & $(0.067)$ & $(0.006)$ & $(0.005)$ & $(0.005)$ \\
\hline Distance Home-Tram & -0.007 & -0.003 & -0.063 & -0.102 & -0.007 & $-0.040^{*}$ & 0.001 \\
& $(0.006)$ & $(0.006)$ & $(0.129)$ & $(0.133)$ & $(0.012)$ & $(0.010)$ & $(0.010)$ \\
\hline Distance Home-Bus & -0.004 & $-0.026^{*}$ & -0.064 & -0.060 & -0.009 & $-0.043^{*}$ & 0.006 \\
& $(0.010)$ & $(0.009)$ & $(0.189)$ & $(0.220)$ & $(0.019)$ & $(0.016)$ & $(0.016)$ \\
\hline & & & & & & & \\
\hline Observations & 67,584 & 67,584 & 34,342 & 67,584 & 28,880 & 34,294 & 34,294 \\
\hline R-squared & 0.278 & 0.351 & 0.029 & & 0.047 & 0.042 & 0.063 \\
\hline Sample mean & 0.512 & 0.582 & 3.22 & 3.22 & 0.418 & 0.294 & 0.332 \\
\hline
\end{tabular}

Notes: See notes in Table 4.

Sources: Johnson, et. al. (1999) and authors' calculations. 
Table A.IV.3 Estimated Effects of Control Variables on Earnings

\begin{tabular}{|c|c|c|c|c|c|c|}
\hline & (1) & (2) & (3) & (4) & (5) & (6) \\
\hline & $\begin{array}{l}\text { Related } \\
\text { to Head }\end{array}$ & $\begin{array}{l}\text { Related to } \\
\text { Head: } \\
\text { Heckman }\end{array}$ & $\begin{array}{l}\text { Related to } \\
\text { Head: } \\
\text { Age }<25 \\
\end{array}$ & $\begin{array}{c}\text { Children } \\
\text { of Head: } \\
\text { Age }<25 \\
\end{array}$ & All & $\begin{array}{c}\text { All: HH } \\
\text { Fixed } \\
\text { Effects }\end{array}$ \\
\hline Age & $\begin{array}{c}0.146^{*} \\
(0.003) \\
\end{array}$ & $\begin{array}{l}0.146^{*} \\
(0.003) \\
\end{array}$ & $\begin{array}{l}0.491^{*} \\
(0.015)\end{array}$ & $\begin{array}{l}0.495^{*} \\
(0.015)\end{array}$ & $\begin{array}{l}0.098^{*} \\
(0.001)\end{array}$ & $\begin{array}{l}0.110^{*} \\
(0.001) \\
\end{array}$ \\
\hline Age $^{2}$ & $\begin{array}{l}-0.002^{*} \\
(0.000) \\
\end{array}$ & $\begin{array}{l}-0.002^{*} \\
(0.000)\end{array}$ & $\begin{array}{l}-0.010^{*} \\
(0.000)\end{array}$ & $\begin{array}{l}-0.010^{*} \\
(0.000)\end{array}$ & $\begin{array}{l}-0.001^{*} \\
(0.000)\end{array}$ & $\begin{array}{l}-0.001^{*} \\
(0.000) \\
\end{array}$ \\
\hline Missing Age & $\begin{array}{l}2.586^{*} \\
(0.039)\end{array}$ & $\begin{array}{l}2.595^{*} \\
(0.038)\end{array}$ & $\begin{array}{l}6.131^{*} \\
(0.140)\end{array}$ & $\begin{array}{l}6.246^{*} \\
(0.143)\end{array}$ & $\begin{array}{l}2.054^{*} \\
(0.022)\end{array}$ & $\begin{array}{c}2.187^{*} \\
(0.030)\end{array}$ \\
\hline Male & $\begin{array}{c}0.266^{*} \\
(0.007) \\
\end{array}$ & $\begin{array}{l}0.266^{*} \\
(0.007) \\
\end{array}$ & $\begin{array}{l}0.211^{*} \\
(0.007)\end{array}$ & $\begin{array}{l}0.202^{*} \\
(0.007)\end{array}$ & $\begin{array}{l}0.321^{*} \\
(0.006)\end{array}$ & $\begin{array}{c}0.272^{*} \\
(0.008) \\
\end{array}$ \\
\hline $\begin{array}{l}\text { Born in } \\
\text { England }\end{array}$ & $\begin{array}{c}0.042^{*} \\
(0.016)\end{array}$ & $\begin{array}{l}0.043^{*} \\
(0.016)\end{array}$ & $\begin{array}{c}0.006 \\
(0.018) \\
\end{array}$ & $\begin{array}{c}0.007 \\
(0.019) \\
\end{array}$ & $\begin{array}{l}0.039^{*} \\
(0.008) \\
\end{array}$ & $\begin{array}{c}0.058^{*} \\
(0.014) \\
\end{array}$ \\
\hline $\begin{array}{l}\text { Born in } \\
\text { London }\end{array}$ & $\begin{array}{c}-0.001 \\
(0.010) \\
\end{array}$ & $\begin{array}{l}-0.001 \\
(0.010) \\
\end{array}$ & $\begin{array}{c}0.016 \\
(0.009) \\
\end{array}$ & $\begin{array}{l}0.018^{*} \\
(0.009)\end{array}$ & $\begin{array}{c}0.003 \\
(0.007) \\
\end{array}$ & $\begin{array}{l}-0.024 \\
(0.014) \\
\end{array}$ \\
\hline $\begin{array}{l}\text { Born and lives } \\
\text { in the same } \\
\text { borough }\end{array}$ & $\begin{array}{c}0.102^{*} \\
(0.008)\end{array}$ & $\begin{array}{l}0.102^{*} \\
(0.008)\end{array}$ & $\begin{array}{c}0.015 \\
(0.008)\end{array}$ & $\begin{array}{c}0.014 \\
(0.008)\end{array}$ & $\begin{array}{l}0.074^{*} \\
(0.005)\end{array}$ & $\begin{array}{c}0.161^{*} \\
(0.010)\end{array}$ \\
\hline $\begin{array}{l}\text { Lives in an } \\
\text { adjacent } \\
\text { borough }\end{array}$ & $\begin{array}{c}0.019 \\
(0.013)\end{array}$ & $\begin{array}{c}0.019 \\
(0.013)\end{array}$ & $\begin{array}{c}0.004 \\
(0.013)\end{array}$ & $\begin{array}{c}0.013 \\
(0.013)\end{array}$ & $\begin{array}{l}0.024^{*} \\
(0.007)\end{array}$ & $\begin{array}{c}0.082^{*} \\
(0.014)\end{array}$ \\
\hline $\begin{array}{l}\text { Hours last } \\
\text { week }\end{array}$ & $\begin{array}{c}0.017^{*} \\
(0.001) \\
\end{array}$ & $\begin{array}{l}0.016^{*} \\
(0.001) \\
\end{array}$ & $\begin{array}{l}0.010^{*} \\
(0.001)\end{array}$ & $\begin{array}{l}0.009^{*} \\
(0.001)\end{array}$ & $\begin{array}{l}0.016^{*} \\
(0.000)\end{array}$ & $\begin{array}{c}0.018^{*} \\
(0.000) \\
\end{array}$ \\
\hline Hours missing & $\begin{array}{c}0.615^{*} \\
(0.036)\end{array}$ & $\begin{array}{l}0.615^{*} \\
(0.036)\end{array}$ & $\begin{array}{l}0.351^{*} \\
(0.041)\end{array}$ & $\begin{array}{l}0.305^{*} \\
(0.041)\end{array}$ & $\begin{array}{l}0.635^{*} \\
(0.024)\end{array}$ & $\begin{array}{c}0.672^{*} \\
(0.028) \\
\end{array}$ \\
\hline Quarrying & $\begin{array}{c}0.056 \\
(0.132) \\
\end{array}$ & $\begin{array}{c}0.056 \\
(0.132) \\
\end{array}$ & $\begin{array}{c}0.136 \\
(0.127) \\
\end{array}$ & $\begin{array}{c}0.129 \\
(0.134) \\
\end{array}$ & $\begin{array}{l}0.167^{*} \\
(0.054)\end{array}$ & $\begin{array}{c}0.132 \\
(0.120) \\
\end{array}$ \\
\hline $\begin{array}{l}\text { Brick/Glass } \\
\text { worker }\end{array}$ & $\begin{array}{c}0.106 \\
(0.099) \\
\end{array}$ & $\begin{array}{c}0.105 \\
(0.099) \\
\end{array}$ & $\begin{array}{c}0.139 \\
(0.087) \\
\end{array}$ & $\begin{array}{c}0.117 \\
(0.089) \\
\end{array}$ & $\begin{array}{l}0.165^{*} \\
(0.048)\end{array}$ & $\begin{array}{c}0.198 \\
(0.084) \\
\end{array}$ \\
\hline Chemicals & $\begin{array}{c}0.178 \\
(0.095) \\
\end{array}$ & $\begin{array}{c}0.179 \\
(0.094) \\
\end{array}$ & $\begin{array}{c}0.184 \\
(0.080) \\
\end{array}$ & $\begin{array}{c}0.178 \\
(0.082) \\
\end{array}$ & $\begin{array}{l}0.170^{*} \\
(0.042) \\
\end{array}$ & $\begin{array}{c}0.196 \\
(0.078) \\
\end{array}$ \\
\hline Metals & $\begin{array}{c}0.144 \\
(0.093) \\
\end{array}$ & $\begin{array}{c}0.144 \\
(0.093)\end{array}$ & $\begin{array}{c}0.134 \\
(0.078)\end{array}$ & $\begin{array}{c}0.132 \\
(0.080) \\
\end{array}$ & $\begin{array}{l}0.174^{*} \\
(0.040)\end{array}$ & $\begin{array}{l}0.165^{*} \\
(0.073)\end{array}$ \\
\hline Electro-plate & $\begin{array}{c}0.090 \\
(0.121) \\
\end{array}$ & $\begin{array}{c}0.090 \\
(0.120)\end{array}$ & $\begin{array}{c}0.107 \\
(0.111)\end{array}$ & $\begin{array}{c}0.079 \\
(0.116)\end{array}$ & $\begin{array}{l}0.240^{*} \\
(0.062)\end{array}$ & $\begin{array}{c}0.144 \\
(0.099) \\
\end{array}$ \\
\hline Electricians & $\begin{array}{c}0.115 \\
(0.093) \\
\end{array}$ & $\begin{array}{c}0.115 \\
(0.093) \\
\end{array}$ & $\begin{array}{c}0.103 \\
(0.079) \\
\end{array}$ & $\begin{array}{c}0.095 \\
(0.081) \\
\end{array}$ & $\begin{array}{l}0.185^{*} \\
(0.041) \\
\end{array}$ & $\begin{array}{c}0.124 \\
(0.075) \\
\end{array}$ \\
\hline Watchmakers & $\begin{array}{c}0.151 \\
(0.115) \\
\end{array}$ & $\begin{array}{c}0.152 \\
(0.114)\end{array}$ & $\begin{array}{c}0.113 \\
(0.090) \\
\end{array}$ & $\begin{array}{c}0.107 \\
(0.092) \\
\end{array}$ & $\begin{array}{l}0.226^{*} \\
(0.055)\end{array}$ & $\begin{array}{c}0.096 \\
(0.098) \\
\end{array}$ \\
\hline Leather & $\begin{array}{c}0.104 \\
(0.095) \\
\end{array}$ & $\begin{array}{c}0.105 \\
(0.094) \\
\end{array}$ & $\begin{array}{c}0.131 \\
(0.079) \\
\end{array}$ & $\begin{array}{c}0.111 \\
(0.081)\end{array}$ & $\begin{array}{l}0.175^{*} \\
(0.043)\end{array}$ & $\begin{array}{c}0.130 \\
(0.077) \\
\end{array}$ \\
\hline Textiles & $\begin{array}{c}0.036 \\
(0.096) \\
\end{array}$ & $\begin{array}{c}0.035 \\
(0.096) \\
\end{array}$ & $\begin{array}{c}0.047 \\
(0.083) \\
\end{array}$ & $\begin{array}{c}0.038 \\
(0.085) \\
\end{array}$ & $\begin{array}{c}0.092 \\
(0.048) \\
\end{array}$ & $\begin{array}{c}0.102 \\
(0.085) \\
\end{array}$ \\
\hline Dressmakers & $\begin{array}{c}0.108 \\
(0.093) \\
\end{array}$ & $\begin{array}{c}0.108 \\
(0.092) \\
\end{array}$ & $\begin{array}{c}0.112 \\
(0.078) \\
\end{array}$ & $\begin{array}{c}0.101 \\
(0.080) \\
\end{array}$ & $\begin{array}{c}0.166^{*} \\
(0.040)\end{array}$ & $\begin{array}{c}0.103 \\
(0.073) \\
\end{array}$ \\
\hline Food/Drink & $\begin{array}{c}0.131 \\
(0.093) \\
\end{array}$ & $\begin{array}{c}0.132 \\
(0.093) \\
\end{array}$ & $\begin{array}{c}0.148 \\
(0.079) \\
\end{array}$ & $\begin{array}{c}0.142 \\
(0.081) \\
\end{array}$ & $\begin{array}{l}0.169^{*} \\
(0.040) \\
\end{array}$ & $\begin{array}{c}0.170 \\
(0.074) \\
\end{array}$ \\
\hline
\end{tabular}




\begin{tabular}{|c|c|c|c|c|c|c|}
\hline Wood & $\begin{array}{c}0.157 \\
(0.094) \\
\end{array}$ & $\begin{array}{c}0.158 \\
(0.093) \\
\end{array}$ & $\begin{array}{l}0.168^{*} \\
(0.079)\end{array}$ & $\begin{array}{l}0.165^{*} \\
(0.081)\end{array}$ & $\begin{array}{l}0.240^{*} \\
(0.040)\end{array}$ & $\begin{array}{l}0.175^{*} \\
(0.073)\end{array}$ \\
\hline Paper & $\begin{array}{c}0.068 \\
(0.094)\end{array}$ & $\begin{array}{c}0.068 \\
(0.093)\end{array}$ & $\begin{array}{c}0.109 \\
(0.079)\end{array}$ & $\begin{array}{c}0.096 \\
(0.081)\end{array}$ & $\begin{array}{l}0.112^{*} \\
(0.042)\end{array}$ & $\begin{array}{c}0.106 \\
(0.075)\end{array}$ \\
\hline Printer & $\begin{array}{c}0.167 \\
(0.094)\end{array}$ & $\begin{array}{c}0.168 \\
(0.094)\end{array}$ & $\begin{array}{l}0.165^{*} \\
(0.079)\end{array}$ & $\begin{array}{c}0.156 \\
(0.081)\end{array}$ & $\begin{array}{l}0.300^{*} \\
(0.041)\end{array}$ & $\begin{array}{l}0.185^{*} \\
(0.075)\end{array}$ \\
\hline Builders & $\begin{array}{c}0.319^{*} \\
(0.095)\end{array}$ & $\begin{array}{c}0.320^{*} \\
(0.094)\end{array}$ & $\begin{array}{l}0.334^{*} \\
(0.081)\end{array}$ & $\begin{array}{l}0.327^{*} \\
(0.083)\end{array}$ & $\begin{array}{l}0.210^{*} \\
(0.040)\end{array}$ & $\begin{array}{c}0.247^{*} \\
(0.074)\end{array}$ \\
\hline Painters & $\begin{array}{c}0.245^{*} \\
(0.095)\end{array}$ & $\begin{array}{c}0.245^{*} \\
(0.095)\end{array}$ & $\begin{array}{l}0.236^{*} \\
(0.080)\end{array}$ & $\begin{array}{l}0.227^{*} \\
(0.082)\end{array}$ & $\begin{array}{l}0.253^{*} \\
(0.041)\end{array}$ & $\begin{array}{c}0.212^{*} \\
(0.075)\end{array}$ \\
\hline $\begin{array}{l}\text { Other } \\
\text { Materials }\end{array}$ & $\begin{array}{c}0.088 \\
(0.095) \\
\end{array}$ & $\begin{array}{c}0.089 \\
(0.094) \\
\end{array}$ & $\begin{array}{c}0.082 \\
(0.080) \\
\end{array}$ & $\begin{array}{c}0.059 \\
(0.082) \\
\end{array}$ & $\begin{array}{l}0.131^{*} \\
(0.043)\end{array}$ & $\begin{array}{c}0.125 \\
(0.079) \\
\end{array}$ \\
\hline Other & $\begin{array}{c}0.049 \\
(0.095) \\
\end{array}$ & $\begin{array}{c}0.049 \\
(0.095) \\
\end{array}$ & $\begin{array}{c}0.072 \\
(0.081) \\
\end{array}$ & $\begin{array}{c}0.065 \\
(0.083) \\
\end{array}$ & $\begin{array}{l}0.121^{*} \\
(0.044 \\
\end{array}$ & $\begin{array}{c}0.072 \\
(0.077) \\
\end{array}$ \\
\hline Transport & $\begin{array}{c}0.084 \\
(0.093) \\
\end{array}$ & $\begin{array}{c}0.085 \\
(0.092) \\
\end{array}$ & $\begin{array}{c}0.136 \\
(0.077) \\
\end{array}$ & $\begin{array}{c}0.131 \\
(0.079) \\
\end{array}$ & $\begin{array}{c}0.127^{*} \\
(0.039) \\
\end{array}$ & $\begin{array}{c}0.112 \\
(0.072) \\
\end{array}$ \\
\hline Finance & $\begin{array}{c}0.074 \\
(0.093) \\
\end{array}$ & $\begin{array}{c}0.075 \\
(0.092) \\
\end{array}$ & $\begin{array}{c}0.098 \\
(0.078) \\
\end{array}$ & $\begin{array}{c}0.099 \\
(0.080) \\
\end{array}$ & $\begin{array}{l}0.109^{*} \\
(0.040)\end{array}$ & $\begin{array}{c}0.064 \\
(0.073) \\
\end{array}$ \\
\hline Public Admin. & $\begin{array}{c}0.556^{*} \\
(0.136) \\
\end{array}$ & $\begin{array}{c}0.560^{*} \\
(0.136) \\
\end{array}$ & $\begin{array}{l}0.728^{*} \\
(0.207) \\
\end{array}$ & $\begin{array}{l}0.647^{*} \\
(0.208) \\
\end{array}$ & $\begin{array}{c}0.453^{*} \\
(0.042) \\
\end{array}$ & $\begin{array}{c}0.381^{*} \\
(0.095) \\
\end{array}$ \\
\hline Professional & $\begin{array}{c}0.402^{*} \\
(0.108)\end{array}$ & $\begin{array}{c}0.402^{*} \\
(0.108)\end{array}$ & $\begin{array}{c}0.285^{*} \\
(0.099)\end{array}$ & $\begin{array}{c}0.259^{*} \\
(0.101)\end{array}$ & $\begin{array}{c}0.391^{*} \\
(0.055)\end{array}$ & $\begin{array}{c}0.343^{*} \\
(0.082)\end{array}$ \\
\hline Entertainment & $\begin{array}{c}0.178 \\
(0.136) \\
\end{array}$ & $\begin{array}{c}0.178 \\
(0.135) \\
\end{array}$ & $\begin{array}{c}0.214 \\
(0.136) \\
\end{array}$ & $\begin{array}{c}0.211 \\
(0.137) \\
\end{array}$ & $\begin{array}{l}0.180^{*} \\
(0.063) \\
\end{array}$ & $\begin{array}{c}0.049 \\
(0.095) \\
\end{array}$ \\
\hline $\begin{array}{l}\text { Personal } \\
\text { Services }\end{array}$ & $\begin{array}{c}-0.148 \\
(0.093) \\
\end{array}$ & $\begin{array}{l}-0.148 \\
(0.093) \\
\end{array}$ & $\begin{array}{l}-0.032 \\
(0.078) \\
\end{array}$ & $\begin{array}{l}-0.002 \\
(0.080) \\
\end{array}$ & $\begin{array}{l}-0.124^{*} \\
(0.040)\end{array}$ & $\begin{array}{c}-0.125 \\
(0.073) \\
\end{array}$ \\
\hline Clerks & $\begin{array}{c}0.279^{*} \\
(0.093) \\
\end{array}$ & $\begin{array}{c}0.279^{*} \\
(0.092) \\
\end{array}$ & $\begin{array}{l}0.249^{*} \\
(0.078) \\
\end{array}$ & $\begin{array}{c}0.238^{*} \\
(0.080) \\
\end{array}$ & $\begin{array}{l}0.333^{*} \\
(0.040) \\
\end{array}$ & $\begin{array}{c}0.224^{*} \\
(0.073)\end{array}$ \\
\hline Warehouse & $\begin{array}{c}0.120 \\
(0.093) \\
\end{array}$ & $\begin{array}{c}0.120 \\
(0.093) \\
\end{array}$ & $\begin{array}{c}0.134 \\
(0.078) \\
\end{array}$ & $\begin{array}{c}0.128 \\
(0.080) \\
\end{array}$ & $\begin{array}{l}0.159^{*} \\
(0.040) \\
\end{array}$ & $\begin{array}{c}0.136 \\
(0.073) \\
\end{array}$ \\
\hline Drivers & $\begin{array}{c}0.297^{*} \\
(0.101)\end{array}$ & $\begin{array}{c}0.299^{*} \\
(0.101)\end{array}$ & $\begin{array}{l}0.269^{*} \\
(0.094)\end{array}$ & $\begin{array}{l}0.265^{*} \\
(0.098)\end{array}$ & $\begin{array}{l}0.167^{*} \\
(0.041)\end{array}$ & $\begin{array}{c}0.200^{*} \\
(0.077)\end{array}$ \\
\hline Other & $\begin{array}{c}0.126 \\
(0.094) \\
\end{array}$ & $\begin{array}{c}0.127 \\
(0.094) \\
\end{array}$ & $\begin{array}{c}0.141 \\
(0.079) \\
\end{array}$ & $\begin{array}{c}0.137 \\
(0.081) \\
\end{array}$ & $\begin{array}{l}0.108^{*} \\
(0.040) \\
\end{array}$ & $\begin{array}{c}0.108 \\
(0.074) \\
\end{array}$ \\
\hline Missing & $\begin{array}{l}-0.090 \\
(0.308)\end{array}$ & $\begin{array}{l}-0.086 \\
(0.307)\end{array}$ & $\begin{array}{c}0.153 \\
(0.175)\end{array}$ & $\begin{array}{c}0.138 \\
(0.182)\end{array}$ & $\begin{array}{c}0.040 \\
(0.121)\end{array}$ & $\begin{array}{c}-0.034 \\
(0.142)\end{array}$ \\
\hline Observations & 15436 & 16566 & 11997 & 11354 & 31668 & 31668 \\
\hline $\mathrm{R}$-squared & 0.572 & & 0.632 & 0.645 & 0.687 & 0.891 \\
\hline F statistic & 173.1 & & & & 601.8 & 370.4 \\
\hline
\end{tabular}

Notes: The omitted occupation is agriculture. See Table 5 for additional results and notes.

Sources: Johnson, et. al. (1999) and authors' calculations. 
Table A.IV.4: Robustness Checks on Distance Estimates in Pay Regressions

\begin{tabular}{|l|c|c|c|c|c|c|c|}
\hline & $(1)$ & $(2)$ & $(3)$ & $(4)$ & $(5)$ & $(6)$ & $(7)$ \\
\hline Distance & $4.738^{*}$ & $3.359^{*}$ & $2.447^{*}$ & $2.451^{*}$ & $2.577^{*}$ & $1.858^{*}$ & $2.992^{*}$ \\
$(0.273)$ & $(0.165)$ & $(0.188)$ & $(0.203)$ & $(0.233)$ & $(0.314)$ & $(0.319)$ \\
\hline Distance $^{2}$ & $-0.0755^{*}$ & $-0.0568^{*}$ & $-0.0392^{*}$ & $-0.0352^{*}$ & $-0.0489^{*}$ & -0.0262 & $-0.0828^{*}$ \\
$(0.0176)$ & $(0.0091)$ & $(0.0112)$ & $(0.0094)$ & $(0.0138)$ & $(0.0174)$ & $(0.0236)$ \\
\hline Demographic & No & Yes & Yes & Yes & Yes & Yes & Yes \\
\hline Occupation & No & No & Yes & Yes & Yes & Yes & Yes \\
\hline $\begin{array}{l}\text { Work } \\
\text { Location }\end{array}$ & No & No & No & Yes & Yes & Yes & Yes \\
\hline Residence & No & No & No & Yes & Yes & Yes & Yes \\
\hline $\begin{array}{l}\text { Other } \\
\text { Distance }\end{array}$ & No & No & No & No & Yes & Yes & Yes \\
\hline $\begin{array}{l}\text { HH Fixed } \\
\text { Effects }\end{array}$ & No & No & No & No & No & Yes & No \\
\hline $\begin{array}{l}\text { One Km } \\
\text { Grids }\end{array}$ & No & No & No & No & No & No & Yes \\
\hline & & & & & & & \\
\hline Observations & 15,436 & 15,436 & 15,436 & 15,436 & 15,436 & 15,436 & 15,185 \\
\hline R-squared & 0.046 & 0.521 & 0.559 & 0.571 & 0.572 & 0.869 & 0.571 \\
\hline F statistic & 381.776 & 1396.455 & 482.596 & 186.829 & 173.123 & 107.874 & 167.752 \\
\hline
\end{tabular}

Note: Estimates based on sample of family members, excluding head of household (column 1, Table 5). See Table 5 for additional notes.

Sources: Johnson, et. al. (1999) and authors' calculations. 
Table A.IV.5: Further Robustness Checks on Distance Estimates in Pay Regressions

\begin{tabular}{|c|c|c|c|c|c|c|c|c|}
\hline & (1) & $(2)$ & (3) & (4) & (5) & (6) & $(7)$ & (8) \\
\hline & $\begin{array}{l}\text { Unlimited } \\
\text { Distance }\end{array}$ & $\begin{array}{c}\text { Armstrong } \\
\text { Skill }\end{array}$ & $\begin{array}{l}\text { Exclude } \\
\text { highest } \\
\text { earner }\end{array}$ & $\begin{array}{c}\text { No } \\
\text { Bartlett } \\
\text { sample }\end{array}$ & $\begin{array}{c}\text { Discrete } \\
\text { Distance: } \\
\text { Non-Head } \\
\text { Family } \\
\end{array}$ & $\begin{array}{c}\text { Discrete } \\
\text { Distance: } \\
\text { All Family }\end{array}$ & $\begin{array}{l}\text { Only } \\
\text { Heads }\end{array}$ & $\begin{array}{c}\text { Discrete } \\
\text { Distance: } \\
\text { Only Heads }\end{array}$ \\
\hline Distance-Work & $\begin{array}{l}2.337^{*} \\
(0.177)\end{array}$ & $\begin{array}{c}2.999^{*} \\
(0.239) \\
\end{array}$ & $\begin{array}{c}3.040^{*} \\
(0.267)\end{array}$ & $\begin{array}{l}2.595^{*} \\
(0.258) \\
\end{array}$ & & & $\begin{array}{c}1.272^{*} \\
(0.167) \\
\end{array}$ & \\
\hline Distance $^{2}$ & $\begin{array}{l}-0.0304^{*} \\
(0.0093)\end{array}$ & $\begin{array}{l}-0.0600^{*} \\
(0.0143)\end{array}$ & $\begin{array}{l}-0.0734^{*} \\
(0.0154)\end{array}$ & $\begin{array}{l}-0.0506^{*} \\
(0.0153)\end{array}$ & & & $\begin{array}{l}-0.0418^{*} \\
(0.0118)\end{array}$ & \\
\hline \multicolumn{9}{|l|}{$\begin{array}{l}\text { Ref: Distance }<0.5 \\
\text { Km }\end{array}$} \\
\hline Distance: $0.5-1$ & & & & & $\begin{array}{c}0.038^{*} \\
(0.013) \\
\end{array}$ & $\begin{array}{l}0.029^{*} \\
(0.009)\end{array}$ & & $\begin{array}{l}0.025^{*} \\
(0.010) \\
\end{array}$ \\
\hline Distance: $1-2$ & & & & & $\begin{array}{l}0.046^{*} \\
(0.012) \\
\end{array}$ & $\begin{array}{c}0.042^{*} \\
(0.008) \\
\end{array}$ & & $\begin{array}{l}0.041^{*} \\
(0.009)\end{array}$ \\
\hline Distance: $2-3$ & & & & & $\begin{array}{l}0.070^{*} \\
(0.013)\end{array}$ & $\begin{array}{l}0.061^{*} \\
(0.009)\end{array}$ & & $\begin{array}{l}0.047^{*} \\
(0.010)\end{array}$ \\
\hline Distance: $3-4$ & & & & & $\begin{array}{l}0.081^{*} \\
(0.014)\end{array}$ & $\begin{array}{l}0.074^{*} \\
(0.009)\end{array}$ & & $\begin{array}{c}0.062^{*} \\
(0.011) \\
\end{array}$ \\
\hline Distance: $4-5$ & & & & & $\begin{array}{l}0.132^{*} \\
(0.016)\end{array}$ & $\begin{array}{c}0.102^{*} \\
(0.010) \\
\end{array}$ & & $\begin{array}{l}0.057^{*} \\
(0.012) \\
\end{array}$ \\
\hline Distance: $5-10$ & & & & & $\begin{array}{l}0.166^{*} \\
(0.015) \\
\end{array}$ & $\begin{array}{l}0.126^{*} \\
(0.009) \\
\end{array}$ & & $\begin{array}{l}0.071^{*} \\
(0.010)\end{array}$ \\
\hline Distance: $10+$ & & & & & $\begin{array}{l}0.236^{*} \\
(0.021) \\
\end{array}$ & $\begin{array}{l}0.183^{*} \\
(0.013) \\
\end{array}$ & & $\begin{array}{l}0.117^{*} \\
(0.013) \\
\end{array}$ \\
\hline Observations & 15,441 & 15,436 & 15,436 & 13,298 & 15,436 & 31,195 & 15,758 & 15,758 \\
\hline $\mathrm{R}$-squared & 0.572 & 0.553 & 0.571 & 0.567 & 0.572 & 0.686 & 0.512 & 0.512 \\
\hline F statistic & 172.912 & 199.754 & 173.805 & 147.639 & 166.068 & 574.471 & 68.871 & 67.419 \\
\hline
\end{tabular}

Notes: See notes in Table 5.

Sources: Johnson, et. al. (1999) and authors' calculations. 
$\underline{\text { Figure A.IV.1. Commuting Destinations for Residents of All Boroughs }}$
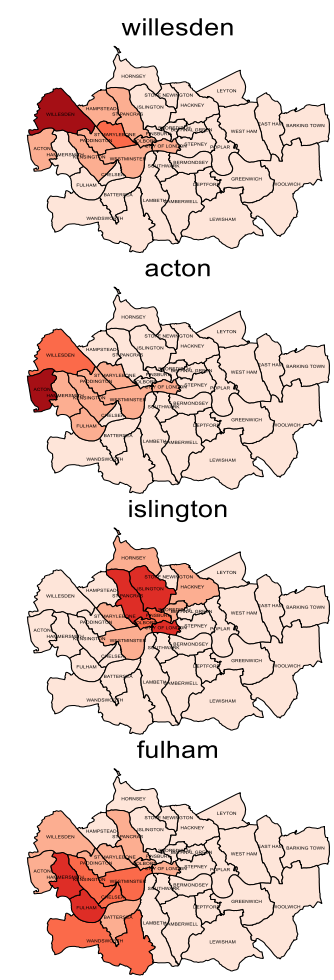

southwark

southwark

ancon

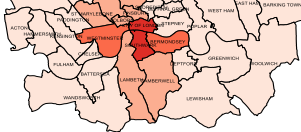

camberwell

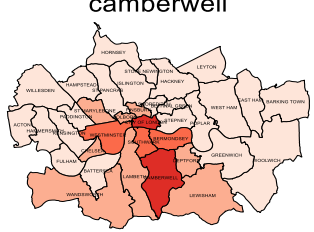

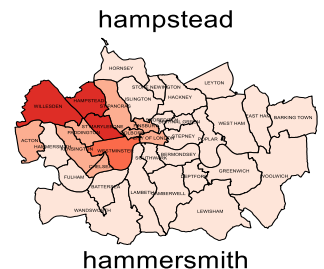

hammersmith
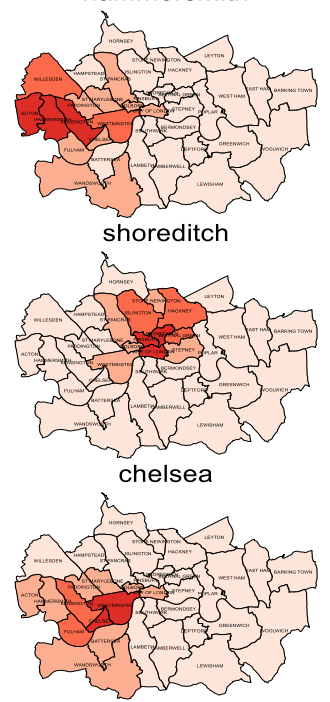

wandsworth
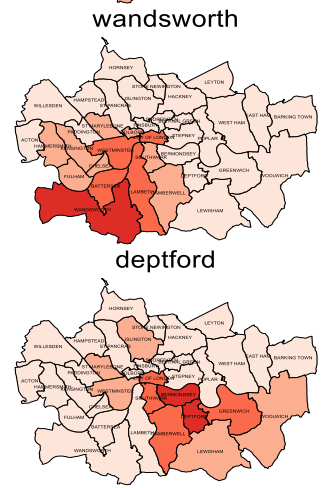

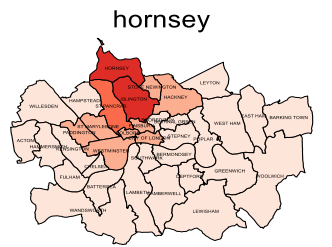

kensington
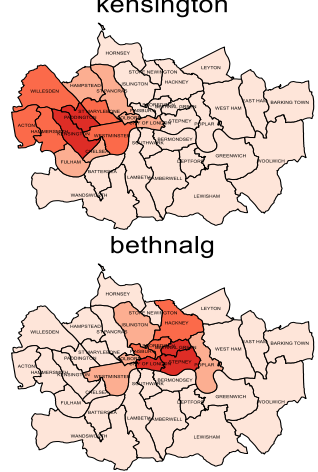

westminster

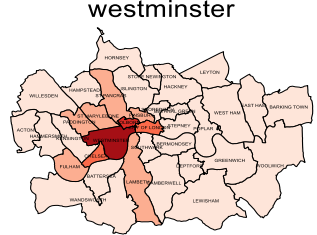

battersea

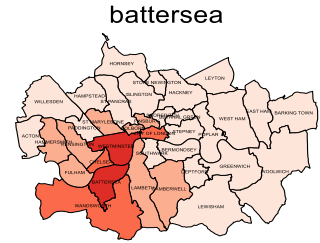

greenwich

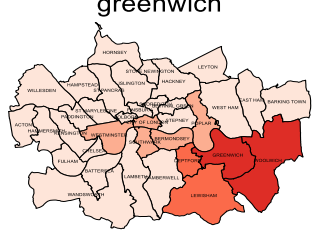

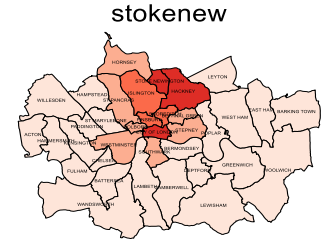

paddington

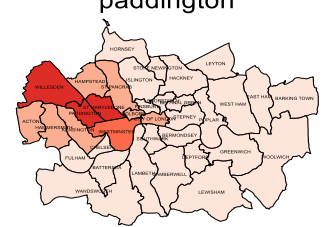

poplar

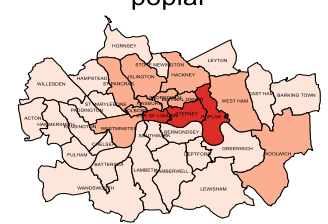

holborn

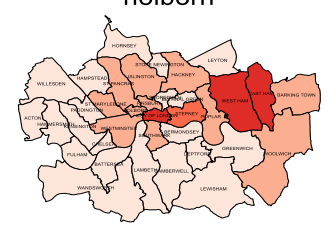

lambeth

(3)

lewisham

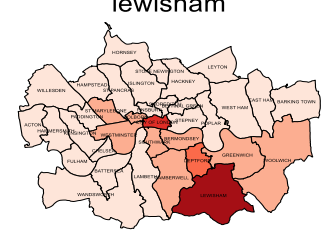

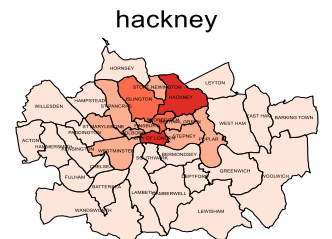

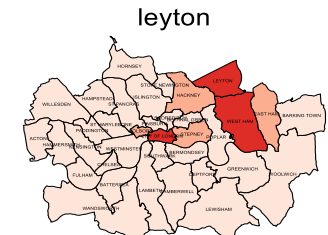

marylebone

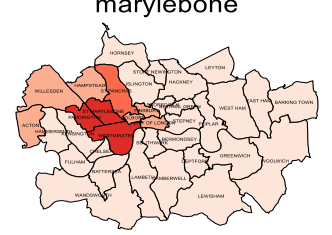

stpancras
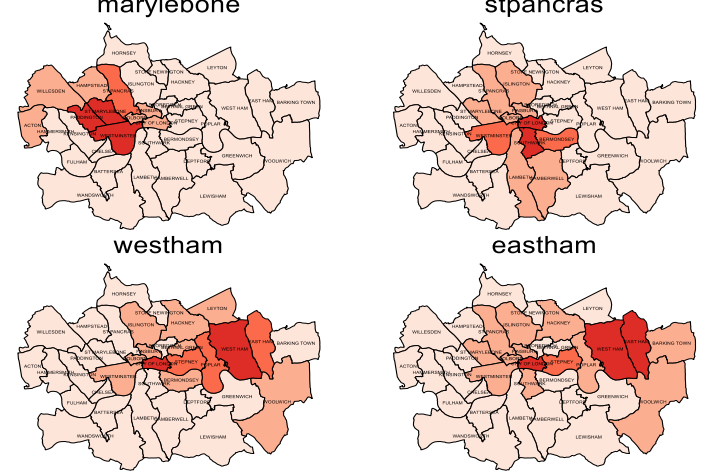

$$
\text { finsbury }
$$
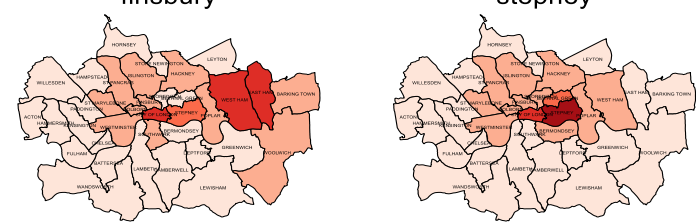

southwark

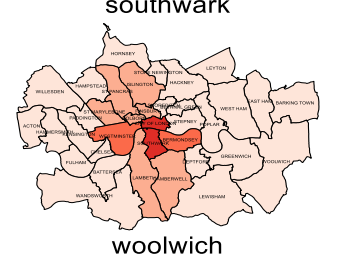

bermondsey
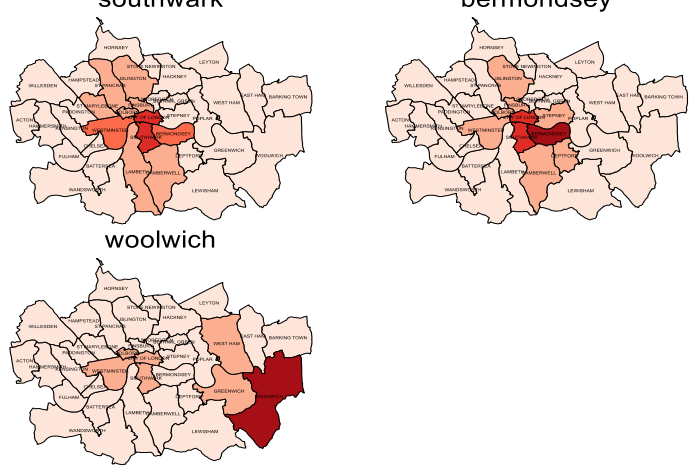